This item was submitted to Loughborough's Research Repository by the author.

Items in Figshare are protected by copyright, with all rights reserved, unless otherwise indicated.

\title{
A risk-adjusted techno-economic analysis for renewable-based milk cooling in remote dairy farming communities in East Africa
}

\section{PLEASE CITE THE PUBLISHED VERSION}

https://doi.org/10.1016/j.renene.2018.06.101

\section{PUBLISHER}

(C) Elsevier

\section{VERSION}

AM (Accepted Manuscript)

\section{PUBLISHER STATEMENT}

This work is made available according to the conditions of the Creative Commons Attribution-NonCommercialNoDerivatives 4.0 International (CC BY-NC-ND 4.0) licence. Full details of this licence are available at: https://creativecommons.org/licenses/by-nc-nd/4.0/

\section{LICENCE}

CC BY-NC-ND 4.0

\section{REPOSITORY RECORD}

Lukuyu, June, Richard Blanchard, and Paul Rowley. 2019. "A Risk-adjusted Techno-economic Analysis for Renewable-based Milk Cooling in Remote Dairy Farming Communities in East Africa”. figshare. https://hdl.handle.net/2134/33891. 


\section{Accepted Manuscript}

A risk-adjusted techno-economic analysis for renewable-based milk cooling in remote dairy farming communities in East Africa

June M. Lukuyu, Richard E. Blanchard, Paul N. Rowley

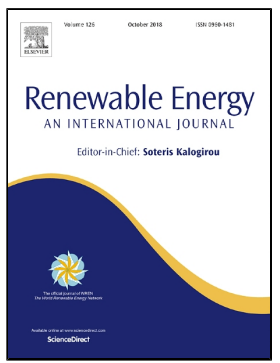

PII: $\quad$ S0960-1481(18)30753-5

DOI: $\quad$ 10.1016/j.renene.2018.06.101

Reference: $\quad$ RENE 10257

To appear in: $\quad$ Renewable Energy

Received Date: $\quad 23$ February 2018

Accepted Date: $\quad 25$ June 2018

Please cite this article as: June M. Lukuyu, Richard E. Blanchard, Paul N. Rowley, A risk-adjusted techno-economic analysis for renewable-based milk cooling in remote dairy farming communities in East Africa, Renewable Energy (2018), doi: 10.1016/j.renene.2018.06.101

This is a PDF file of an unedited manuscript that has been accepted for publication. As a service to our customers we are providing this early version of the manuscript. The manuscript will undergo copyediting, typesetting, and review of the resulting proof before it is published in its final form. Please note that during the production process errors may be discovered which could affect the content, and all legal disclaimers that apply to the journal pertain. 


\section{A risk-adjusted techno-economic analysis for renewable-based milk cooling in remote dairy}

2 farming communities in East Africa

3 June M. Lukuyu a, ${ }^{\text {,* }}$ Richard E. Blanchard a, Paul N. Rowley a

$4{ }^{\text {a }}$ CREST (Centre for Renewable Energy Systems Technology), Wolfson School of Mechanical Electrical and Systems Engineering, Loughborough University, Leics. LE11 3TU, UK

* Corresponding author at: 600 Main Street, Worcester, Massachusetts 01608, USA. Tel: +1 4132757283

E-mail addresses: junelukuyu@gmail.com (J.M. Lukuyu), R.E.Blanchard@lboro.ac.uk (R.E. Blanchard), P.N.Rowley@lboro.ac.uk (P.N. Rowley).

\section{ABSTRACT}

The dairy industry accounts for 9-14\% of East Africa's agricultural gross development product. Due to lack of milk cooling facilities, dairy farmers in areas without access to reliable grid electricity face problems of high milk spoilage and limited access to formal markets, which limits their income and standard of living. This article examines the economic viability for a number of configurations of off-grid solar, wind, biomass and biogas based milk-cooling systems serving a community in Tanzania. Key risk factors having the greatest impact on system viability are identified and a stochastic approach, by means of a Monte Carlo simulation is employed to determine the risk-adjusted economic performance of the project. The results indicate that biogas based systems offer the most viable option, with an internal rate of return of around $25 \%$, a net present value of around $\$ 9,000$ and a projected increase in farmers' monthly income of at least $78 \%$. Despite specific risk factors, the 300 -liter cooling system had an $82 \%$ probability of a positive net present value. However, larger system cooling capacities have a significant likelihood of a financial loss. Consequently, risk mitigation strategies designed to increase the probability of economic success are proposed.

Keywords: Renewable energy, Off-grid, Milk cooling, Economics, Monte Carlo, East Africa

\begin{tabular}{|c|c|c|c|}
\hline \multicolumn{4}{|c|}{ Nomenclature } \\
\hline A & $\operatorname{area}\left(\mathrm{m}^{2}\right)$ & ICE & internal combustion engine \\
\hline $\mathrm{A}_{\text {days }}$ & days of autonomy & IRR & internal rate of return \\
\hline $\mathrm{AC}$ & alternating current & $\mathrm{MC}$ & Monte Carlo \\
\hline $\mathrm{CF}$ & expected cash flow per period & NASA & National Aeronautics and Space Administration \\
\hline $\mathrm{C}_{\mathrm{p}}$ & specific heat $\left(\mathrm{kJkg}^{-1} \mathrm{~K}^{-1}\right)$ & NPV & net present value \\
\hline $\mathrm{CH}_{4}$ & methane & PV & photovoltaic \\
\hline $\mathrm{d}$ & discount rate & TDBP & Tanzania Domestic Biogas Program \\
\hline $\mathrm{DC}$ & direct current & Tzs & Tanzanian shilling ( 1 USD $\sim 2200 \mathrm{Tzs}$ ) \\
\hline DF & derate factor & $\mathrm{VaR}$ & value-at-risk \\
\hline DoD & battery depth of discharge $(\%)$ & VARS & vapor absorption refrigeration system \\
\hline $\mathrm{E}$ & electrical energy $(\mathrm{kWh})$ & VCRS & vapor compression refrigeration system \\
\hline $\mathrm{E}[\mathrm{x}]$ & expected value of random variable, $\mathrm{X}$ & & \\
\hline $\mathrm{F}_{\mathrm{R}}$ & heat removal factor & Subscripts & \\
\hline $\mathrm{G}_{\mathrm{T}}$ & solar irradiance $\left(\mathrm{kWh} / \mathrm{m}^{2}\right.$.day $)$ & $\mathrm{a}$ & ambient \\
\hline HRT & hydraulic retention time (days) & array & photovoltaic array \\
\hline I & current (amperes) & $\mathrm{B}$ & boiler \\
\hline LHV & low heating value $\left(\mathrm{MJ} / \mathrm{kg}, \mathrm{MJ} / \mathrm{m}^{3}\right)$ & batt & battery \\
\hline $\mathrm{LiBr}$ & lithium bromide & BG & biogas \\
\hline M & mass (kg) & $\mathrm{BM}$ & biomass \\
\hline $\mathrm{N}$ & number & $\mathrm{c}, \mathrm{i}$ & collector inlet \\
\hline $\mathrm{NH}_{3}$ & ammonia & $\mathrm{CM}$ & cow manure \\
\hline $\mathrm{P}$ & power $(\mathrm{kW})$ & co & solar collector \\
\hline Q & thermal energy $(\mathrm{kWh})$ & dig & digester \\
\hline q & quantity & $\mathrm{e}$ & evaporator \\
\hline $\mathrm{R}_{\mathrm{CH} 4}$ & Percentage of methane in biogas & G & gasifier \\
\hline Rton & refrigeration ton & gen & generator \\
\hline $\mathrm{SGC}$ & specific gas consumption $\left(\mathrm{m}^{3} / \mathrm{kWh}\right)$ & HW & hot water \\
\hline $\mathrm{S}_{\mathrm{p}}$ & peak sun-hours & inv & inverter \\
\hline $\mathrm{t}$ & time & oc & open circuit \\
\hline $\mathrm{T}$ & temperature $\left({ }^{\circ} \mathrm{C}\right)$ & PG & producer gas \\
\hline $\mathrm{U}_{\mathrm{L}}$ & collector heat transfer coefficient $\left(\mathrm{W} \cdot \mathrm{m}^{-2} \cdot \mathrm{K}^{-1)}\right.$ & $\mathrm{pv}$ & photovoltaic module \\
\hline UA & storage tank heat loss $(\mathrm{kW} / \mathrm{K})$ & st & storage tank \\
\hline $\mathrm{V}$ & volume $\left(\mathrm{m}^{3}\right)$ & tnk & refrigeration tank \\
\hline $\mathrm{v}$ & wind speed $(\mathrm{m} / \mathrm{s})$ & tot & system total \\
\hline VS & quantity of volatile solids per $\mathrm{kg}$ manure $(\mathrm{kg})$ & tur & turbine \\
\hline $\mathrm{V}_{\mathrm{t}}$ & voltage (volts) & & \\
\hline $\mathrm{V}_{\mathrm{B}}$ & $\mathrm{m}^{3}$ of biogas generated per $\mathrm{kg}$ organic fertilizer & Greek symbols & \\
\hline $\mathrm{x}$ & random input variable & $\sigma$ & standard deviation \\
\hline$\tilde{y}$ & project net present value & $\Upsilon$ & gas yield $\left(\mathrm{m}^{3} / \mathrm{kg}\right)$ \\
\hline & & $\eta$ & efficiency \\
\hline Acronyms & & $\alpha$ & absorbance \\
\hline BOS & balance of system & $\Delta, \delta$ & change \\
\hline $\mathrm{COP}$ & coefficient of performance & $\rho$ & density $\left(\mathrm{kg} / \mathrm{m}^{3}, \mathrm{~kg} / \mathrm{l}\right)$ \\
\hline GDP & gross development product & $\tau$ & transmittance \\
\hline
\end{tabular}




\section{Introduction}

Agriculture plays a crucial role in the economy of sub-Saharan Africa and has proven fundamental in alleviating rural poverty and creation of employment. The East African region, encompassing Kenya, Tanzania and Uganda, is predominantly rural, with over $80 \%$ of its inhabitants deriving its livelihood heavily from agriculture. Dairy production, which is one of the most important sub-sectors of agriculture, involves over $40 \%$ of Africa's cattle resource and represents $68 \%$ of the continent's milk output [1]. The dairy industry in Kenya, Uganda and Tanzania accounts for 13\% [2], 9\% [3] and 14\% [4] respectively of agricultural gross development product, GDP.

Historically, the majority of small-scale dairy farmers in East Africa have lacked the technology, training and market access to grow their businesses. In the recent past, various projects, such as the More Milk in Tanzania (MoreMilkiT) project [5], have been launched to help marginalized small-scale dairy farmers in rural areas of East Africa to improve on-farm dairy production, get better access to markets and increase competitiveness. The project employs a dairy market hub, DMH, approach, which is a collective arrangement that aims to stimulate grouping of dairy farmers to produce more milk in bulk, thereby facilitating entry into milk markets and enabling group access to inputs and services such as animal health, nutrition and breeding training, credit services, and transportation [6]. One of the functional models of a dairy market hub revolves around chilling plants. The chilling hub model is exclusively owned by the dairy farmers, who elect a committee, which hires experienced managers to manage the hub and its facilities. This model has been successful in revolutionizing the dairy industry. Fig. 1 illustrates the basic elements of a DMH model with a chilling plant [7].

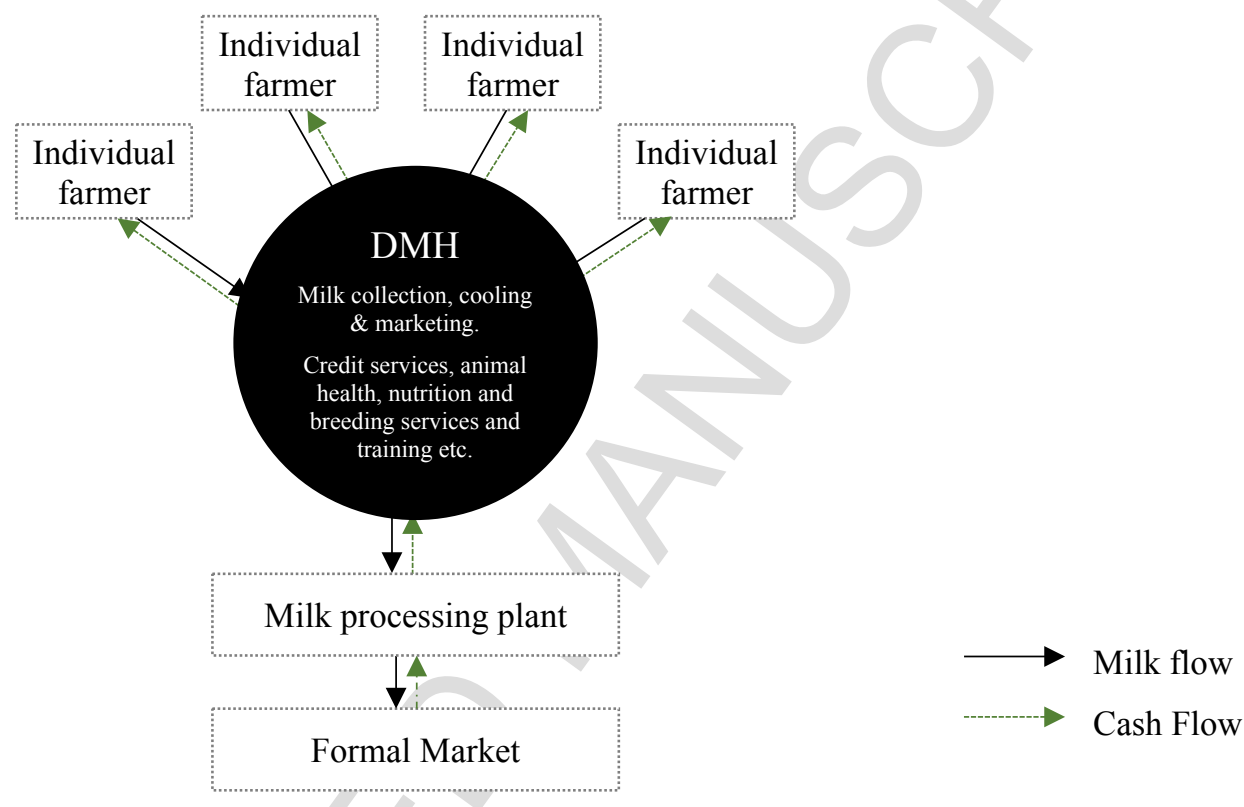

Fig. 1. Basic elements of a dairy market hub model with a chilling plant

The chilling hubs implemented to date in East Africa are located only in areas with access to reliable grid electricity, locking out many small-scale dairy farmers in remote locations where there is poor infrastructure, limited road access and transportation services and limited access to electricity. These farmers face the challenge of high milk spoilage and limited access to dairy markets due to lack of cooling facilities. Milk is collected and transported to market once daily; therefore, wastage is significant and the income from milk production significantly reduced. In a wider geographical context, according to Food and Agriculture Organization (FAO) statistics, post-harvest milk losses in most developing regions without access to reliable grid electricity is approximately $21 \%$ [8].

Where power grid does not exist, or is at a far distance, the use of renewable sources such as solar, wind, hydro and biomass can improve energy access for rural communities. Renewable energy technologies can be particularly suitable in these contexts because they can provide small-scale, decentralized energy supply that meet the needs of populations most widely affected by energy poverty. Previous research into small-scale renewable energy-based milk cooling systems in isolated regions has primarily focused on their technical feasibility, particularly with regards to solar milk cooling systems and energy storage in the form of a battery bank or thermal ice storage. Studies [9], [10] which analysed the performance and reliability of photovoltaic (PV) refrigeration plants under several climatic and load disturbances, showed good efficiency, reliability and system autonomy at solar radiation values greater than $5 \mathrm{kWh} / \mathrm{m}^{2} /$ day, and increasing specific total energy consumption with increasing ambient temperatures.

Regardless of the technical viability of a given renewable energy system, a robust analysis of its economic feasibility is required as part of any due diligence process. However, few studies on renewable-powered milk cooling systems have included economic analyses. Work [11] on solar-powered domestic refrigeration systems in India showed that whilst technically feasible, economic viability would require significant support such as carbon credits or a government subsidy. A similar study [12], done in India, determined a hybrid biomass-biogas gas milk cooling system to be economically viable as opposed to a solar-based system. Several studies on the economic viability of off-grid hybrid energy systems have also assessed the sensitivity of economic viability to changes in uncertain input factors, and showed that fluctuations in fuel prices represent a significant risk to system viability [13], [14].

Numerous renewable energy projects fail to deliver expected returns on investment because of unforeseeable future events such as changes within energy markets, environmental hazards, equipment breakdown, vandalism and regulatory and policy changes. Whilst it 
is impossible to accurately predict future trends and events, effective risk analysis is critical for any potential investor in order to assess

financial viability and to support effective decision-making. For example, studies on small-scale solar projects have shown that uncertainty about future system prices, operation costs, revenues and interest rates can reduce project internal rate of return (IRR) by up to $45 \%$. [15], [16].

The aim of this research is to evaluate alternative configurations of a renewable-based stand-alone milk cooling system, together with the conditions for developing economically feasible systems. An off-grid renewable energy-based chilling hub business model, which offers milk bulking, cooling and marketing services, as well as group access to animal nutrition and health services, credit services, training and transportation services at a competitive price for a small-scale rural dairy farming community in East Africa, is proposed. Additionally, the objectives include assessing the sensitivity of financial viability to changes in input variables such as supply and demand, future technology prices and resource variability, and to evaluate key investment risks using a probabilistic approach. The structure of the remainder of the paper is as follows: the process of selecting the study area and determining the milk-cooling requirement is described in section 2 and 3. Assessment of the available renewable resources is presented in section 4, followed by refrigeration and power generation technology sizing, as well as model development in section 5. Results from the techno-economic and risk analyses are presented in section 6. A schematic overview of the proposed approach is shown in Fig. 2.

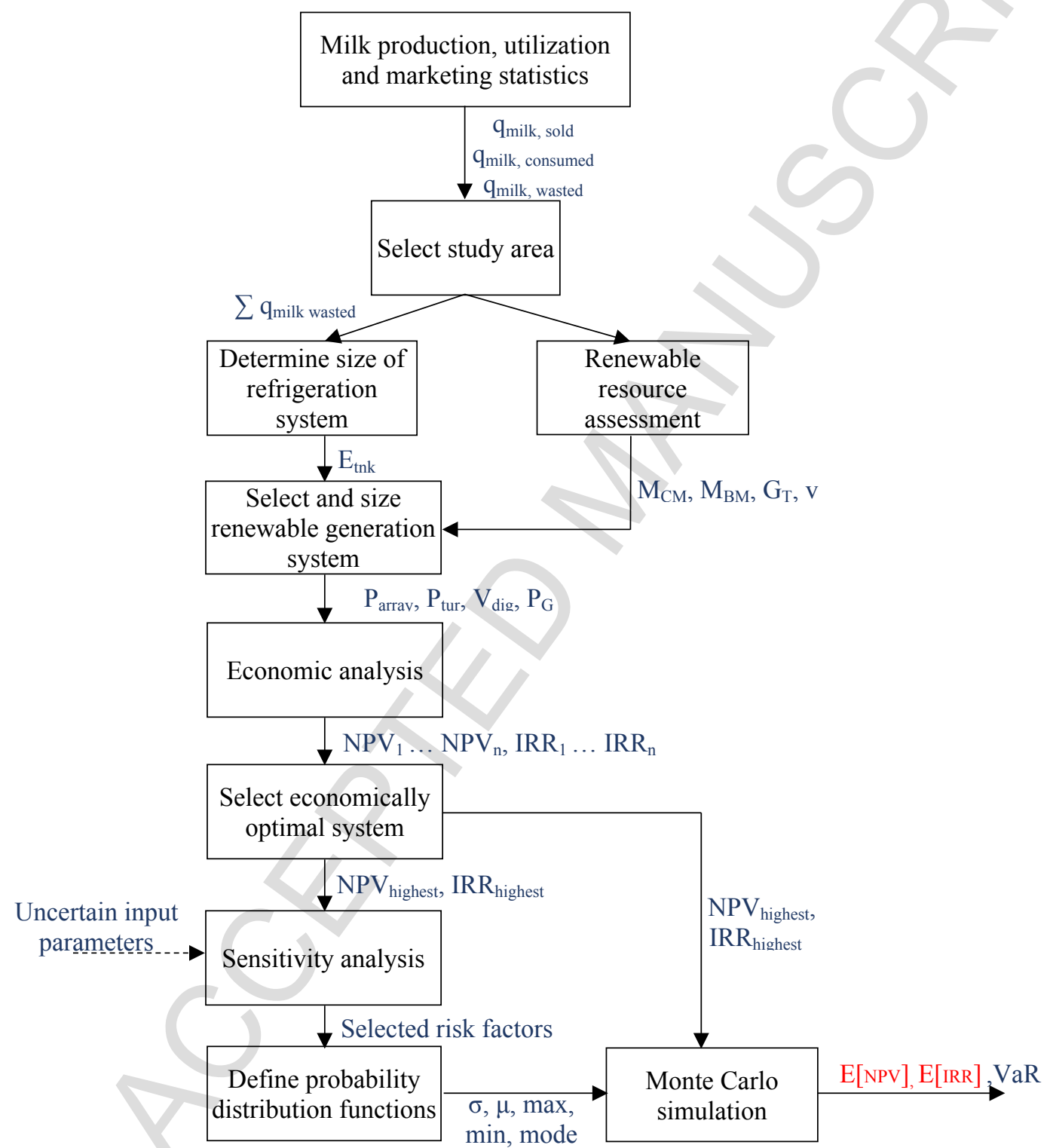

Fig 2: Overview of proposed method for risk-adjusted techno-economic analysis for a renewable based milk cooling system 


\section{Site Selection}

Using Tanzania as the case study area, data collected at the end of 2012 [17] pertaining to milk production, utilization and marketing patterns among small-scale dairy farmers in Morogoro and Tanga regions (Fig. 3) was analysed to determine a target community that

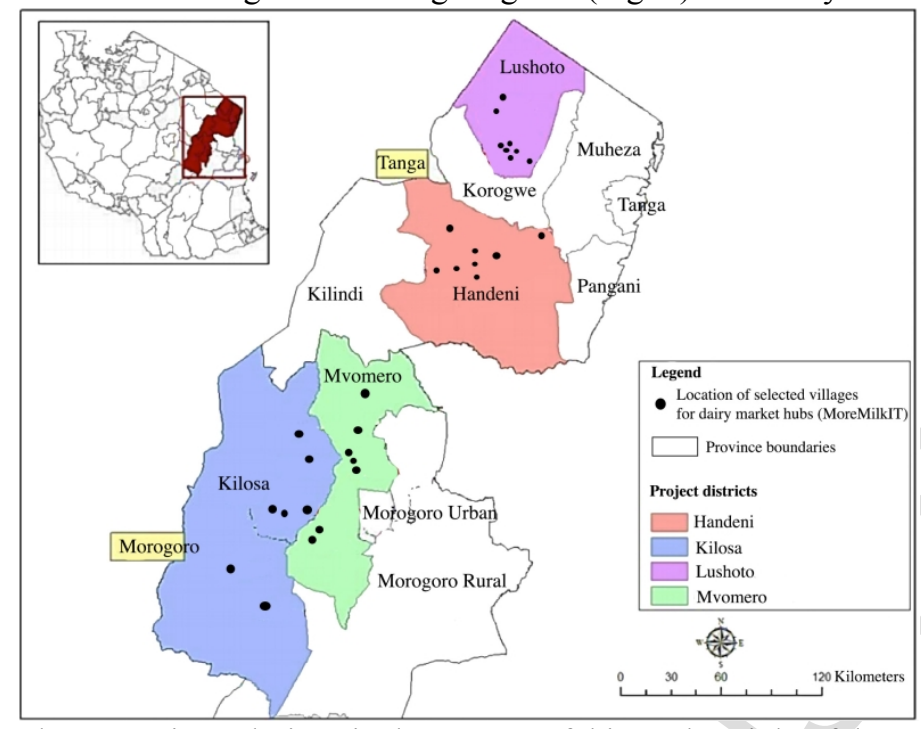

best encompasses the challenges and prospective solutions in the context of this study. Eight of the twenty-one communities participating in dairy market hubs were considered, primarily because they included larger household sample sizes.

Fig. 3. Small-scale rural dairy farming regions in North-east Tanzania

Previous work [18] carried out in the southern highlands of Tanzania to investigate the determinants of access to market by smallholder dairy farmers showed that low frequency of milk sales per day or week and high household milk consumption were significant indicators $(\mathrm{P}<0.001)$ of farmers' poor market access. Data for each household on the average daily quantities of fresh milk produced, sold and consumed as shown in Fig. 4 was therefore used in selecting a target community.

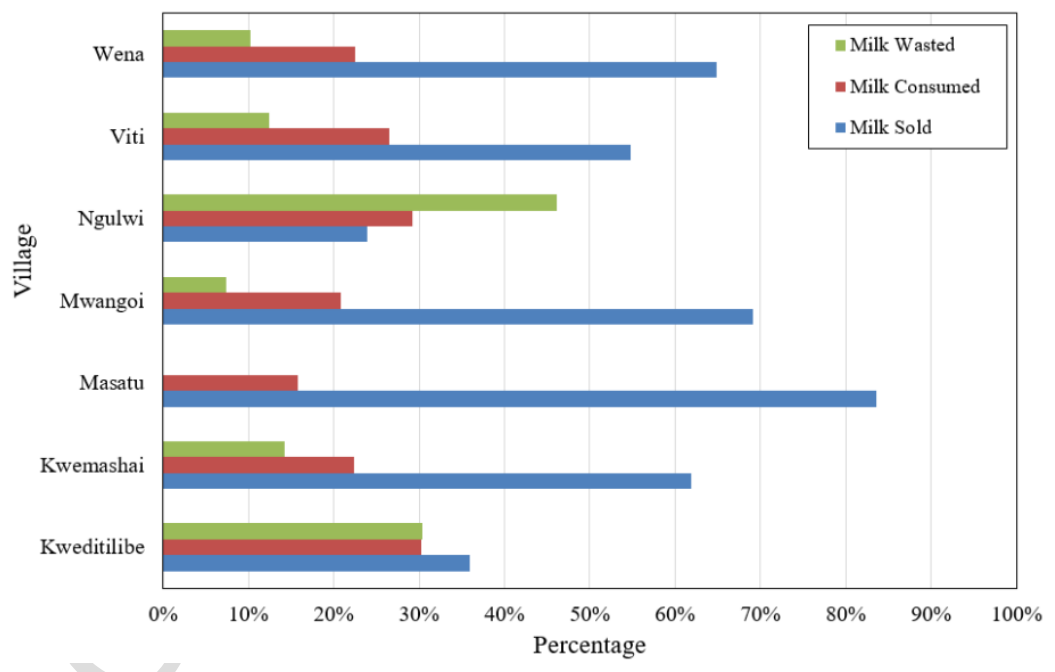

Fig. 4. Milk production, utilization and marketing patterns of case study communities

Only $24 \%$ of the daily milk produced in Ngulwi village, located in Lushoto district, is sold, $29 \%$ is consumed, and an average of $47 \%$ goes to waste per household, therefore indicating poor access to dairy markets.

\section{Milk cooling demand}

Population and household size data, and the average quantity of daily milk wasted per household were used to determine the milkcooling requirement of the community in litres.

Ngulwi village has a population of 2,677 [19]. Survey data [17], determined the community to have approximately 229 cattle keeping households, with an average of 2.9 litres of milk being wasted per day per household. This suggested that there is significant potential to bulk, cool and market as much as 664 litres of milk per day. Small-scale dairy systems are sensitive to local weather conditions; a decline in milk production is usually reported during the dry season, most commonly due to shortages of water and pasture [20]. Thus, to account for seasonal fluctuations in the level of milk production and the geographical placement of the households in relation to each other, the economies of scale of the system was evaluated by considering a range of cooling requirements. 
A large quantity of milk in Tanzania is marketed within the urban and peri-urban areas. Milk collection lorries commonly receive milk twice a day from milk collection centres in nearby villages for delivery to the factory, where it is pasteurised and packed [21]. This study is therefore based on the assumption that the milk cooling tanks are operated overnight to store evening milk and during the day to store the morning milk; and that all milk is purchased and sold at specified farm gate and factory gate prices every day of the year. However, since milk prices are highly variable and uncertain, a sensitivity analysis is essential in determining how varying milk prices impact the economics of the system.

\section{Renewable resource assessment}

The focus on the renewable resources in this study was limited to solar, wind and bioenergy, given their suitability for deployment at a small-scale level.

\subsection{Solar resource}

Monthly average daily solar insolation on a horizontal surface $\left(\mathrm{kWh} / \mathrm{m}^{2} \mathrm{~d}\right)$ and air temperature $\left({ }^{\circ} \mathrm{C}\right)$ data averaged over a 22 -year period was obtained from the National Aeronautics and Space Administration (NASA) meteorology and solar energy database [22]. The annual average daily insolation received in Ngulwi, averaged over a 22-year period, between 1983 and 2005 , was determined to be 5.29 $\mathrm{kWh} / \mathrm{m}^{2}$.day [22]. The maximum monthly average daily insolation of $6.43 \mathrm{kWh} / \mathrm{m}^{2}$ is experienced in February, which is also the hottest month, with a monthly average air temperature of $25^{\circ} \mathrm{C}$. The minimum monthly average daily insolation of $4.16 \mathrm{kWh} / \mathrm{m}^{2}$ occurs in June, with a monthly average air temperature of $23.6^{\circ} \mathrm{C}$ as shown in Fig. 5.

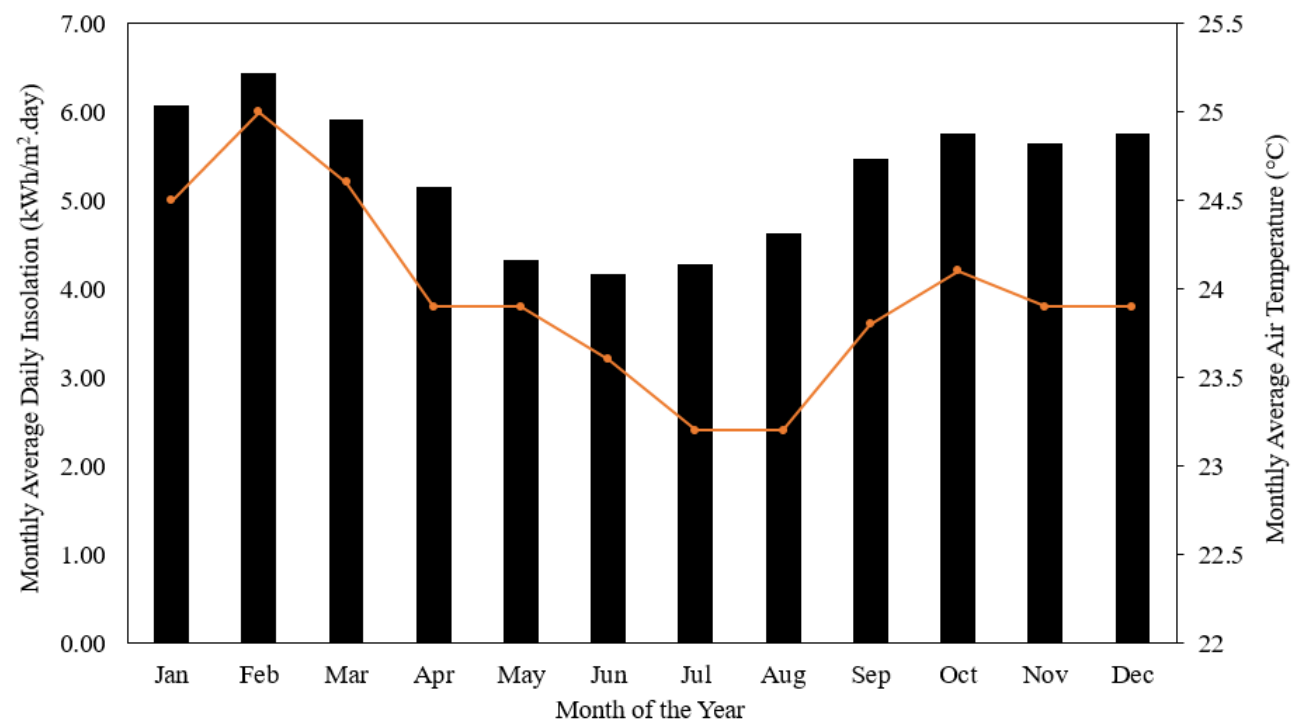

Fig. 5. Monthly average daily insolation incident on a horizontal surface and air temperature data over a 22-year period [22]

This solar resource represents good potential for solar energy conversion given that small-scale solar photovoltaic technologies have been shown to be viable above approximately $4 \mathrm{kWh} / \mathrm{m}^{2}$.day, with larger installations requiring $5 \mathrm{kWh} / \mathrm{m}^{2}$.day or above [23]. Although the solar resource in this area does not exhibit strong seasonal changes, it is significant that daily average insolation data over a period of six months, between January $1^{\text {st }}$ and June $30^{\text {th }} 2005$, shows high variability (Fig. 6). Thus, incorporation of correctly sized energy storage is crucial in balancing the energy supply and demand in real time.

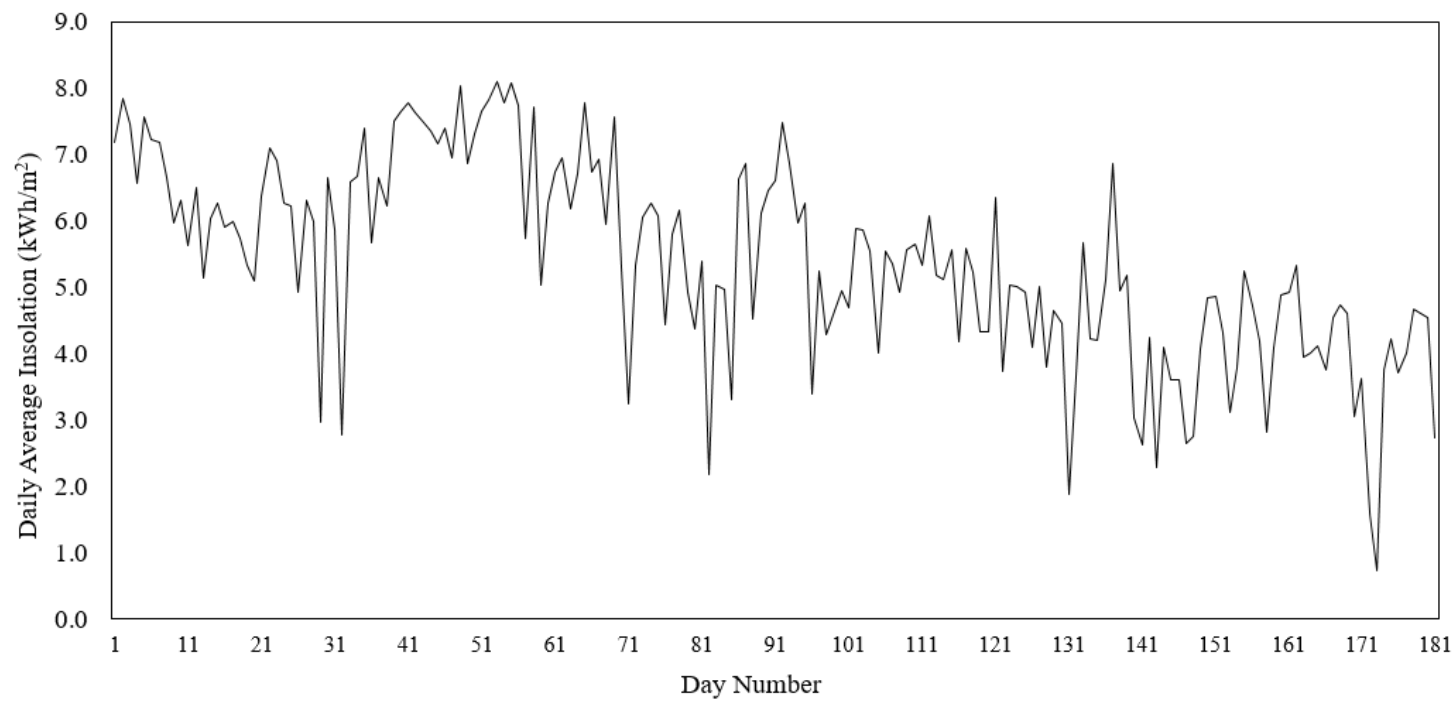


Fig. 6. Daily average insolation incident on a horizontal surface between January $1^{\text {st }}$ and June $30^{\text {th }}, 2005$ [22]

\subsection{Wind resource}

According to the 2015 World Bank Tanzania wind resource mapping report [24], the highest mean wind speeds are observed in the northern and central regions along the mountain ridges, with average wind speeds exceeding $8 \mathrm{~m} / \mathrm{s}$. Due to the sheltering effect of the mountains, the north-eastern region, which encompasses the study area, experiences lower wind speeds. Monthly averaged wind speed data recorded at a height of $10 \mathrm{~m}$ above the ground and averaged over 10 years, between 1995 and 2005 was obtained from the NASA meteorology and solar energy database [22]. The annual average wind speed of Ngulwi was determined to be $4.0 \mathrm{~m} / \mathrm{s}$, with monthly average values ranging between $3.1 \mathrm{~m} / \mathrm{s}$ and $4.8 \mathrm{~m} / \mathrm{s}$ as shown in Fig. 7 .

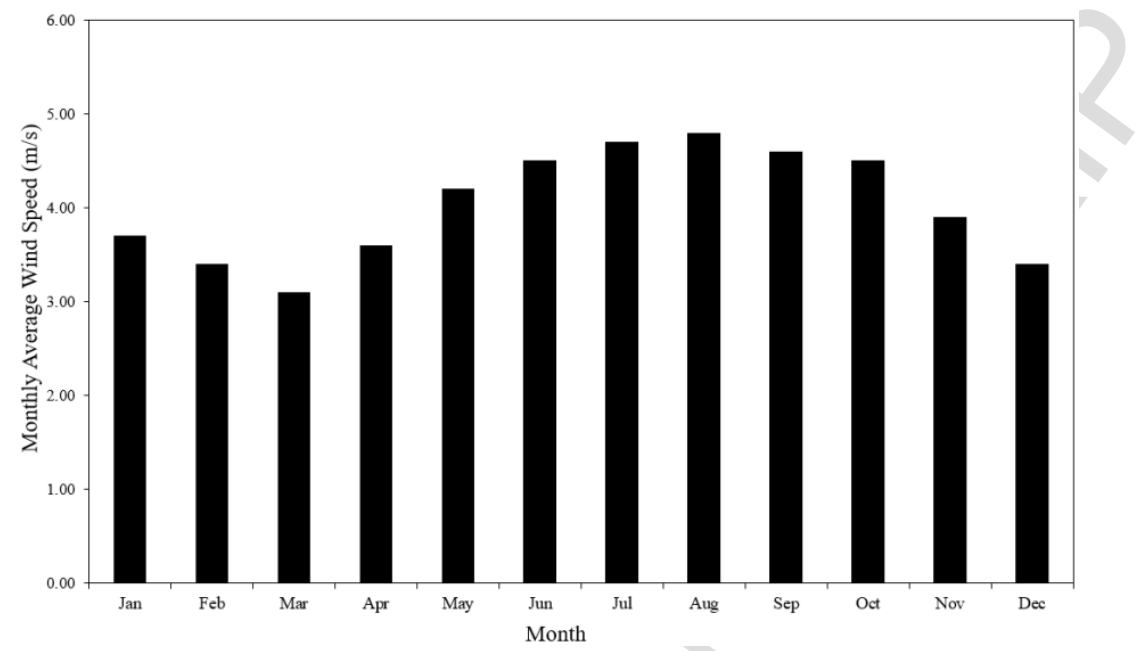

Fig. 7. Monthly wind speed averaged over 10 years [22]

\subsection{Bioenergy resource}

Tanzania has a considerable potential for biomass from forest residues (1.1 million tons/year) and agricultural residues, such as sugarcane bagasse (613,950 tons/year), coffee husks (12,307 tons/year), rice husks (326,220 tons/year), sisal waste (622,800 tons/year), cashew nut shells (33,167 tons/year) and tobacco stems (37,632 tons/year) [25]. There are over 200 sawmills across the country, each producing up to 3 tons of wood waste per hour [26]. Currently, this waste material is not utilized and is therefore the primary focus in the present study.

Biogas energy potential from cattle manure in the target community, Ngulwi, was determined based on the herd size per household and the number of cattle-keeping households in the community. The survey data indicated that there is an average of two dairy cows per household, and a total herd of 458 . Given a typical daily manure production of about $18 \mathrm{~kg}$ per cow of approximately $300 \mathrm{~kg}$ live weight [27], and considering partial manure collection at $80 \%$ (which is typical for dairy cattle in confinement [28]), the quantity of substrate that is potentially available in the study area was calculated to be 6.59 tones/day. This is sufficient for the operation of the locally available biogas technologies [29]. The availability of a local water resource is critical to the technical potential of biogas. Biogas installations require a 1:1 mixture ratio of manure and water and even with the minimum feeding of the smallest installations, the water requirement is approximately 25 liters a day [30]. In a previous survey carried out in seven villages in Lushoto to analyze the characteristics of specific farming systems, multiple sources of water were found to be adequate for farming and additional practices [31]. Thus, the availability of water in the present study area was deemed sufficient for the biogas application in question.

\subsection{Energy storage}

Solar and wind energy resources have variable and uncertain outputs that do not necessarily match the level of demand in real time. To be reliable as primary energy sources, energy storage (or back-up generation) is required. For this study, it is assumed that excess energy will be stored and subsequently released when energy demand exceeds supply. For an energy storage system to be cost effective, it should be designed in light of the specific application it is intended to support. Lead acid battery technology is generally preferred in the East African market because of its technological maturity and availability, as well as lower cost relative to lithium ion-based technology. Thus, this study considers lead-acid storage technology, given its suitability for micro-scale, off-grid use $(<10 \mathrm{~kW})$ [32], [33].

\section{Methodology}

\subsection{Technology options and sizing}

The stand-alone renewable based milk cooling system configurations in this study were designed based on the available renewable resources and locally available renewable technologies suitable for small scale, off-grid operation. For each of the following 
technologies, technical data presented in Table 1 and cost data presented in Table 2 were obtained from a number of local East African

vendors, together with relevant industry databases.

Table 1

Technology options technical data

\begin{tabular}{lll}
\hline Technical Parameter & Value & Reference \\
\hline Fuel heating value (sawdust) & $16.54 \mathrm{MJ} / \mathrm{kg}$ & {$[34]$} \\
Fuel heating value (biogas) & $23 \mathrm{MJ} / \mathrm{m}^{3}$ & {$[35]$} \\
Heating value producer gas & $4.6 \mathrm{MJ} / \mathrm{m}^{3}$ & {$[36]$} \\
Biogas specific yield & $0.208 \mathrm{~m}^{3} / \mathrm{kgVS}$ & {$[37]$} \\
Boiler efficiency & $78 \%$ & {$[38]$} \\
Inverter efficiency & $94 \%$ & {$[39]$} \\
Lead acid battery efficiency & $85 \%$ & {$[40]$} \\
Specific fuel wood consumption & $30 \mathrm{~kg} / \mathrm{h}$ & {$[41]$} \\
Specific producer gas consumption (100\% load) & $3.24 \mathrm{~m}^{3} / \mathrm{kWh}$ & {$[42]$} \\
Production gas yield (gasifier) & $1.67 \mathrm{~m}^{3} / \mathrm{kg}$ & {$[42]$} \\
Specific biogas consumption & $1.21 \mathrm{~m}^{3} / \mathrm{kWh}$ & {$[43]$} \\
Specific heat of milk & $3.93 \mathrm{KJkg}-\mathrm{K}^{-1}$ & {$[12]$} \\
Density of milk & $1.035 \mathrm{~kg} / \mathrm{liter}$ & {$[12]$} \\
Battery lifetime & 8 years & {$[40]$} \\
PV array lifetime & 25 years & {$[44]$} \\
Wind turbine lifetime & 30 years & {$[45]$} \\
Ammonia-water absorption chiller lifetime & 20 years & {$[46]$} \\
Combustion engine operating hours & 20,000 hours & {$[43]$} \\
\hline
\end{tabular}

Table 2

Technology options cost data

\begin{tabular}{llll}
\hline Technology & Investment cost & $\mathrm{O} \& \mathrm{M}$ cost & References \\
\hline Direct expansion VCRS & $\$ 6.70 /$ litre & $2.5 \%$ of installed cost & Quoted cost by vendor \\
Robur ACF absorption chiller & $\$ 6,970 / \mathrm{Rton}$ & $2.0 \%$ of installed cost & {$[12]$} \\
Thermosyphon & $\$ 130 / \mathrm{kW}$ & & {$[47]$} \\
Storage tank & $\$ 1.14 /$ litre & - & Quoted cost by vendor \\
Solar collector system (plus balance of system, BOS) & $\$ 425 / \mathrm{m}^{2}$ & $2.5 \%$ of installed cost & {$[47]$} \\
Canadian solar PV modules (plus BOS) & $\$ 2,040 / \mathrm{kW}$ & $2.5 \%$ of installed cost of PV & {$[44]$} \\
True Power sine wave inverter & $\$ 570 / \mathrm{kW}$ & system & {$[39]$} \\
205 Ah, 12V Veep cycle lead acid battery & $\$ 392$ each & $5 \%$ of installed cost & {$[40]$} \\
BWC Excel wind system (plus BOS) & $\$ 4,595 / \mathrm{kW}$ & $5]$ & {$[45]$} \\
Biomass gasifier with Internal Combustion Engine (ICE) & $\$ 2,890 / \mathrm{kW}$ & $\$ 0.097 / \mathrm{kWh}$ & {$[41]$} \\
Biomass gasifier with boiler & $\$ 1,880 / \mathrm{kW}$ & $\$ 0.06 / \mathrm{kWh}$ & {$[38]$} \\
Fixed dome bio-digester & $\$ 137.16 / \mathrm{m}^{3}$ & $2.4 \%$ of installed cost & {$[49]$} \\
Biogas modified ICE & $\$ 462 / \mathrm{kW}$ & $($ digester \& generator) & {$[43]$} \\
Biogas burner and boiler & $\$ 54.39 / \mathrm{m}^{3}$ & - & {$[12]$} \\
\hline
\end{tabular}

\subsubsection{Vapor Compression Refrigeration System (VCRS)}

The direct expansion VCRS is the most widely utilized refrigeration system in milk cooling equipment. It employs a cooling mechanism whereby refrigerant gas flows inside copper pipes around the surface of the milk cooling tank, consuming about $2.31 \mathrm{~W} /$ litre of electricity [50]. The ice bank VCRS, which uses an ice bank and chilled water reservoir located at the base of the tank, is rarely used for milk cooling tanks of capacities less than 2,000 litres because of its high investment costs. In addition, contrast to the direct expansion tanks, which cool milk within four hours, the ice bank tanks, are more suited to areas with a reliable supply of grid electricity because they need to operate for at least ten hours per day [50]. It was therefore excluded from this study. A schematic of typical configurations of different stand-alone renewable-powered VCRS is illustrated in Fig 8. 


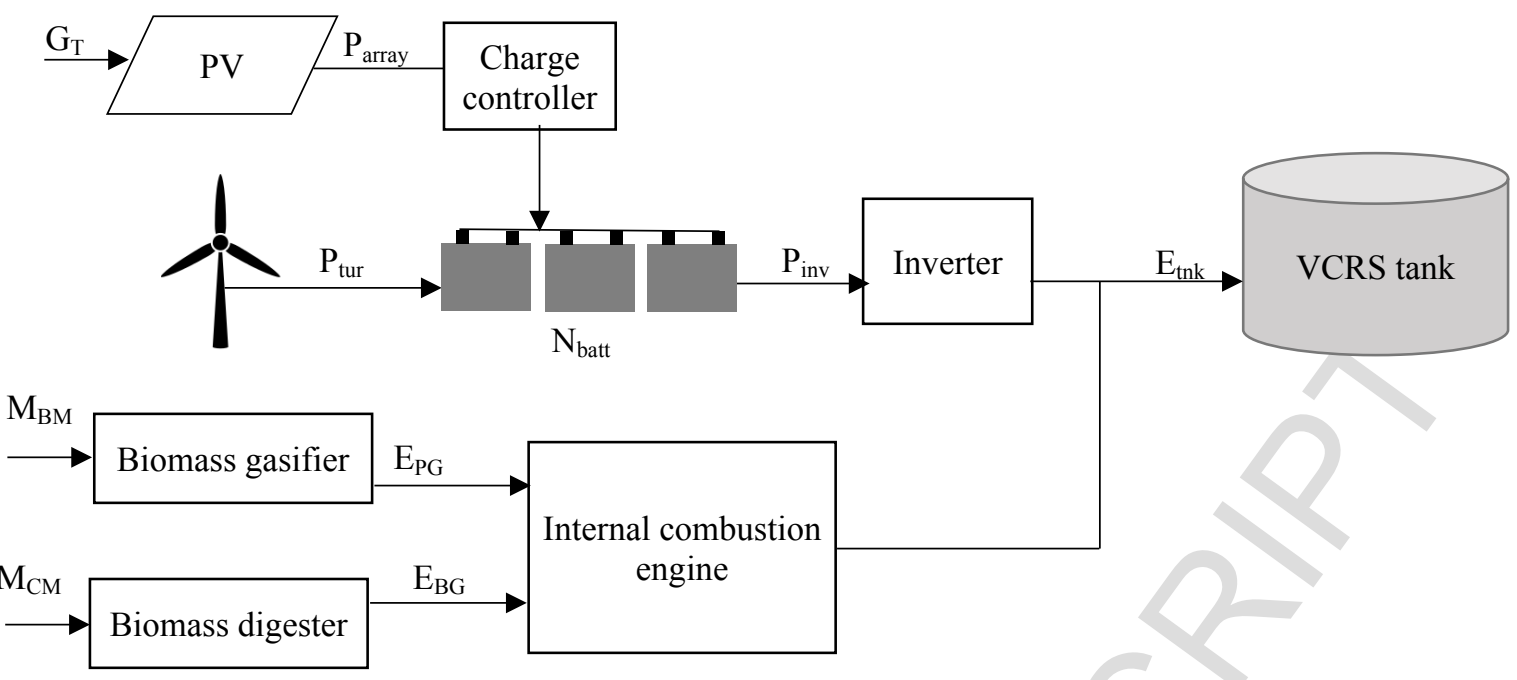

Fig. 8. Schematic of different configurations of a renewable-powered VCRS for milk cooling

An inverter is required to convert the direct current (DC) from the PV array or wind turbine to the VCRS's alternating current (AC). It is designed to meet the total AC connected load in watts. The inverter power output required is therefore determined by [51]:

$$
\mathrm{P}_{\text {inv }}=\mathrm{P}_{\text {tnk }} / \eta_{\text {inv }}
$$

The energy storage capacity of the battery bank ( $\mathrm{kWh}$ ) required, given by Eq. 2 [52], is a function of the daily load, days of autonomy, and the depth of discharge, which is typically $50 \%$ for lead acid batteries [53]. The number of batteries in parallel is then calculated by dividing $\mathrm{E}_{\text {batt }}$ by the battery's 72-hour energy rating [40], which is for 3 days of autonomy. The number of batteries in series is calculated by dividing the battery voltage by the system voltage, which was selected as 24 VDC for the PV system and 48 VDC for the wind turbine system.

$$
\mathrm{E}_{\text {batt }}=\left(\mathrm{E}_{\text {tnk }} \cdot \mathrm{A}_{\text {days }}\right) / \mathrm{DoD}
$$

Off-grid PV systems are typically designed for the month of the year with the lowest insolation so that the system will work when the sun is least available [54]. The PV based systems are therefore sized to meet the daily cooling requirements during the least sunny month of June, which has a mean daily horizontal radiation of $4.16 \mathrm{kWh} / \mathrm{m}^{2}$. The required output of the PV array is therefore calculated using Eq. 3 [51]. The PV array was assumed to be at an optimum fixed tilt angle with no shading and a derating factor of 0.82 [55].

$$
P_{\text {array }}=\frac{P_{\text {inv }} \cdot P_{p v}}{\eta_{\text {batt }} \cdot D F_{p v} \cdot S_{p} \cdot I_{o c} \cdot V_{t, o c}}
$$

Biomass gasification technology has not been extensively implemented in Tanzania despite the abundance of biomass resource. However, a few small-scale biomass gasification systems for electrification have been installed across the country [56] [57]. Eq. 4 [42] gives the energy balance of the downdraft gasifier system considered in this study.

$$
\mathrm{E}_{\text {tnk }}=\mathrm{E}_{\mathrm{PG}} \cdot \eta_{\mathrm{ICE}}=\frac{\mathrm{M}_{\mathrm{BM}} \cdot \Upsilon_{\mathrm{PG}}}{\mathrm{SGC}_{\mathrm{PG}}} \text { where } \eta_{\mathrm{ICE}}=\frac{\mathrm{E}_{\text {tnk }}}{\mathrm{LHV}_{\mathrm{PG}} \cdot \mathrm{M}_{\mathrm{BM}} \cdot \Upsilon_{\mathrm{PG}}}
$$

Overall efficiency of the gasifier system was calculated by [42].

$$
\eta_{\text {tot }}=\frac{\operatorname{LHV}_{\mathrm{PG}} \cdot \mathrm{V}_{\mathrm{PG}}}{\mathrm{LHV}_{\mathrm{BG}} \cdot \mathrm{M}_{\mathrm{BM}}}
$$

Small-scale biogas systems are well established in Tanzania. Over 12,000 fixed-dome biogas plants have been installed in rural households since 2009 as part of the Tanzania Domestic Biogas Program, TDBP [58]. The volume of the anaerobic digester, which was based on the quantity of substrate and the retention time required for the organic matter of the substrate to be fully converted to gas, is given by Eq. 6 [59]. A ratio of 1:1 was assumed for the water-substrate mixture and an additional $20 \%$ of the digester volume was assigned for the gas.

$$
\mathrm{V}_{\text {dig }}=1.2 \mathrm{HRT}\left[\frac{\mathrm{M}_{\mathrm{CM}}}{\rho_{\mathrm{CM}}}+\mathrm{V}_{\text {water }}\right] \text { where } \mathrm{M}_{\mathrm{CM}}=\frac{\mathrm{E}_{\mathrm{tnk}} \cdot \mathrm{SGC}_{\mathrm{BG}}}{\mathrm{\Upsilon}_{\mathrm{BG}} \cdot \mathrm{VS}_{\mathrm{CM}}}
$$

Bio-slurry, obtained from the biogas plant is considered a good source of organic fertilizer. Therefore, prospective income from composted bio-slurry, which is preferred over the liquid form to avoid the transportation hurdle and the dried form to avoid nutrient loss [60], was considered in this study. 
Wind energy in Tanzania is mainly used to pump water for irrigation and to meet domestic and livestock needs, with limited utilization for electricity generation [61]. The BWC Excel-R wind turbine, which was designed for small-scale off-grid use was selected for the present study [62]. The power output of the wind farm, $\mathrm{P}_{\mathrm{tur}}$, is calculated from the expected power output of the turbine at each wind speed, determined from the wind turbine's power curve (Fig. 9) and the wind probability, calculated using the Weibull distribution function given by Eq. 8 [63]. The $\mathrm{k}$ and c Weibull parameters for this study were assumed to be 2 and 0.143 respectively [64].

$$
f(v)=\left[\left(\begin{array}{l}
k \\
c
\end{array}\right) \cdot\left(\begin{array}{l}
v \\
c
\end{array}\right)^{k-1} \cdot e^{-(v / c)^{k}}\right]
$$

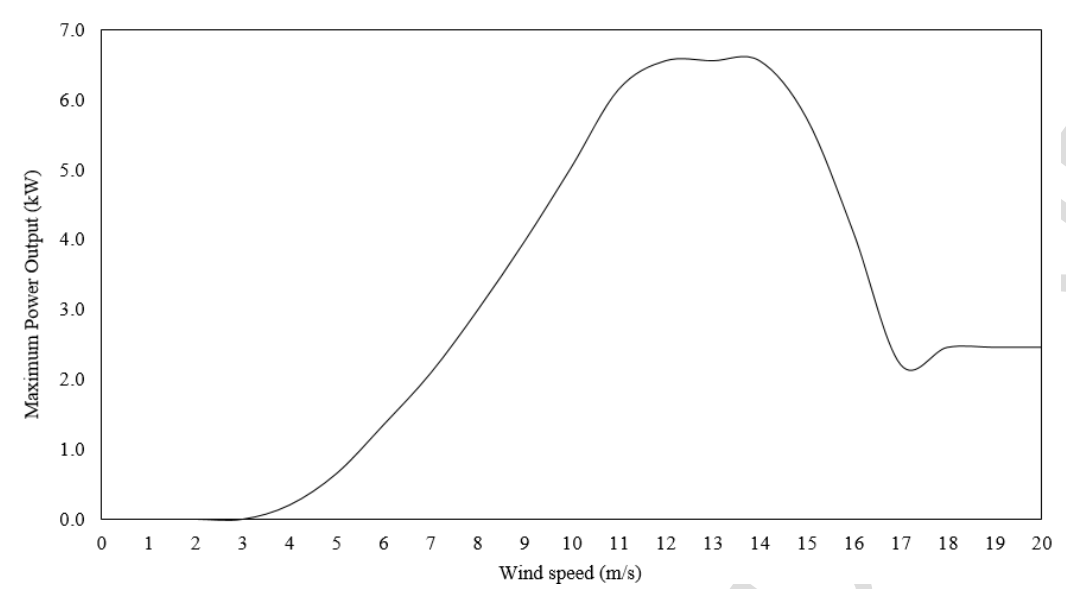

Fig. 9. Power curve for BWC Excel-R wind turbine [64]

\subsubsection{Vapor Absorption Refrigeration System (VARS)}

Vapour absorption systems, with Lithium Bromide(LiBr)-water or Ammonia(NH) $)_{3}$-water refrigerant-absorbent pair, use heat to drive the cooling cycle and produce chilled water while consuming a small amount of electricity to run the pump, which circulates the mixture. The $\mathrm{NH}_{3}$-water VARS is preferred because the $\mathrm{LiBr}$-water VARS cannot be operated below $5^{\circ} \mathrm{C}$ [12]. The energy source may be steam, hot water or waste heat. The daily thermal energy required to power the VARS to cool milk from $35^{\circ} \mathrm{C}$ to $4^{\circ} \mathrm{C}$ in 4 hours [65] was determined using a mass energy balance of the system, illustrated in Fig 10 and given by Eq. 9 - 13 [66] [67]. The use of thermosiphon systems, such as the one used in [68], eliminates the need for an electrical pump. Instead, the system is operated by repositioning control valves twice a day.

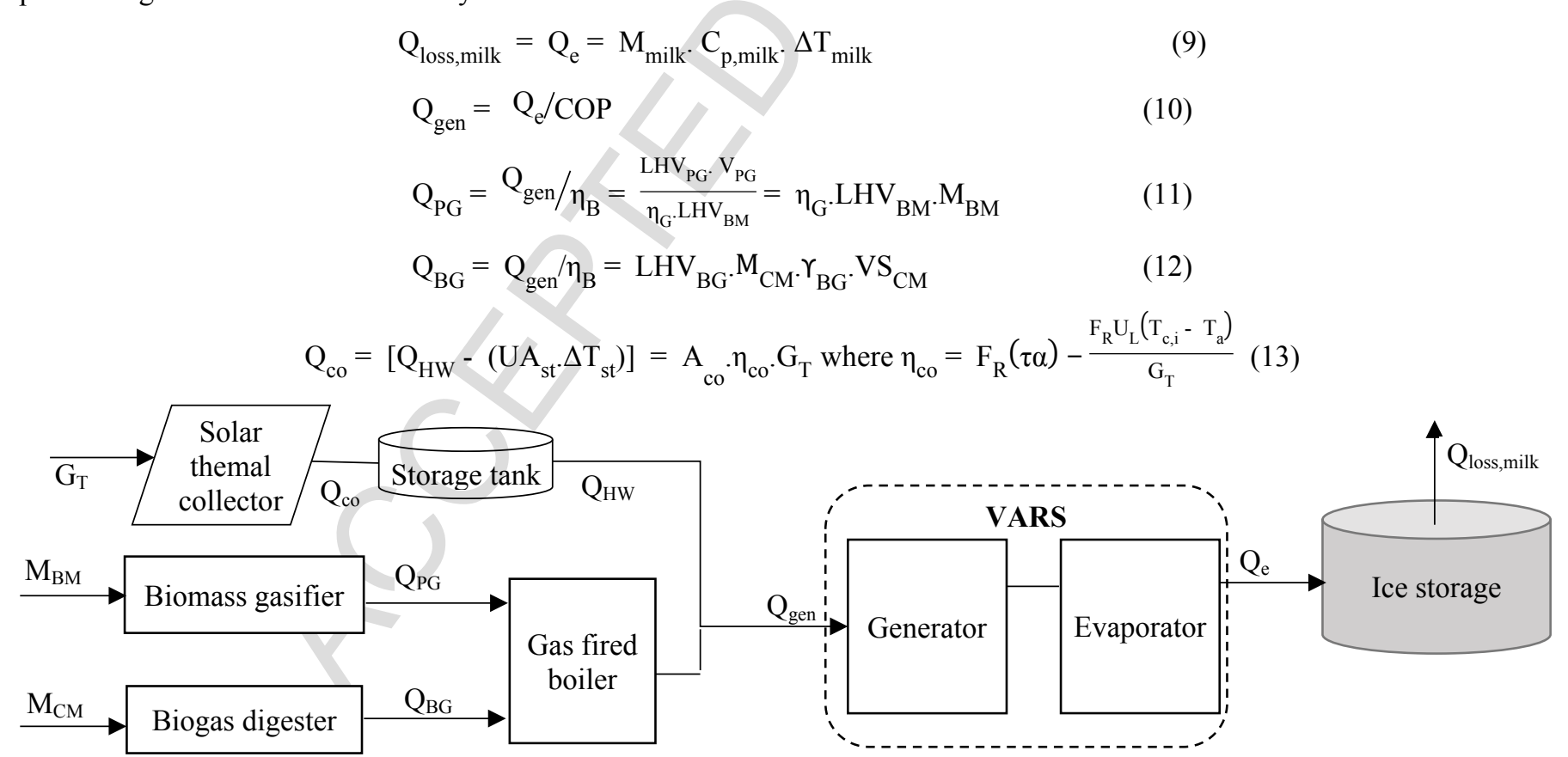

Fig 10. Schematic of different configurations of a renewable-powered VARS for milk cooling

\subsection{Model development}


The model developed for this study is composed of three parts: (a) an economic model, which characterizes the economic performance of the system configurations above at different sizes (b) a sensitivity model, which evaluates the sensitivity of the economic performance of the systems to changes in the uncertain input parameters, and (c) a risk model, which adjusts the economic aspects of the systems to reflect the risk associated with the uncertain input variables, as well as determining the probability of the project being profitable.

\subsubsection{Economic Model}

The economic performance of each candidate system is characterized via a discounted cash flow analysis yielding internal rates of return and net present values. Net present value, NPV, is a parameter that expresses the initial capital investment and all future cash flows arising from operating the system over its lifetime as an equivalent amount at the present time (zero). When the calculated NPV is positive, the investment is projected to be profitable, whilst an NPV of zero indicates break even. The net present value is given by:

$$
\mathrm{NPV}=\sum_{\mathrm{t}=0}^{\mathrm{n}} \frac{\mathrm{CF}_{\mathrm{t}}}{(1+\mathrm{d})^{\mathrm{t}}}
$$

where $\mathrm{CF}_{\mathrm{t}}$ is the expected cash flow per time period, $\mathrm{t}, \mathrm{n}$ is the investment period, which is 10 years in this study, and $\mathrm{d}$ is the discount rate. [69] and [70] reported the economic opportunity cost of capital (discount rate) in Kenya and Rwanda as 12\% and 13\% respectively. Thus, a discount rate of $12 \%$, (which is also the current discount rate used by the Central Bank of Tanzania [71]) was used in this study. The IRR, which is the percentage profit an investor would expect to gain each year was calculated by setting the NPV to zero and solving for the discount rate.

The baseline project economic parameters, including fuel cost, water tariff and milk prices were referenced from published East African sources and are presented in Table 3.

\section{Table 3}

Baseline input project economic parameters

\begin{tabular}{lll}
\hline Parameter & Value & References \\
\hline Fuel cost (cattle manure) & $\$ 10.04 /$ ton & {$[72]$} \\
Fuel cost (sawdust) & $\$ 17.00 /$ ton & Vendor quote \\
Tanzania average water tariff & $\$ 0.46 \mathrm{per} \mathrm{m}^{3}$ & {$[73]$} \\
Composted bio-slurry cost & $\$ 93.00 /$ ton & {$[74]$} \\
Farm gate milk price (buying price from farmers) & $\$ 0.31$ per litre & {$[75]$} \\
Factory gate milk price (selling price to milk processors) & $\$ 0.34$ per litre & {$[75]$} \\
Inflation rate & $5.6 \%$ & {$[76]$} \\
\hline
\end{tabular}

\subsubsection{Sensitivity Model}

A sensitivity analysis was carried out to determine the impact of uncertain parameters on the economic performance of the system configurations projected to be profitable. Selected parameters were varied systematically within a $+/-50 \%$ range, while all other input variables were kept constant to determine their impact on the NPV and IRR of the system. The related deviations of the NPV and IRR from its base-case value were recorded, generating a sensitivity characteristic model in the form of a spider graph. The parameters, which resulted in more than a 50\% change in the NPV of the system from its base-case value for a $50 \%$ increase or decrease in its value, were prioritised for further risk analysis.

\subsubsection{Risk Model}

A number of methods such as scenario and value-at-risk analysis have been used to quantify risks affecting investments in renewable energy. The present study utilized the Monte Carlo (MC) simulation method [77], which is the most widely used value-at-risk (VaR) approach for such assessments. The MC method involves varying several uncertain input parameters simultaneously, and calculates probabilities of outputs being less or more than a target value. Thus, the effects of variations in a project's design on project risk can also be determined [78]. However, this method requires information on the probability distributions of uncertain input parameters, which can be difficult to ascertain. In addition, it may not be reliable in situations of significant volatility, such as during periods of political and economic instability. In addition, a relatively large number of iterations are needed to obtain reliable results, which can be time consuming with computationally complex models.

Triangular and normal probability distributions are often used in estimating cost risks. The triangular distribution is described by the minimum, maximum and mode values of the uncertain parameter, while the normal distribution is described by its mean and standard deviation [79]. In this study, different probability distributions were used for different uncertain parameters. An MC simulation with 10,000 iterations was performed, with resultant NPV and IRR probability distributions being generated. The cumulative risk of a negative project $\mathrm{NPV}, \mathrm{R}_{\mathrm{NPV}<0}$ is determined by [78]:

$$
\mathrm{R}_{\mathrm{NPV}<0}\left(\mathrm{x}_{1} \ldots \mathrm{x}_{\mathrm{n}} ; \mathrm{i}_{\mathrm{D}}\right)=\int_{-\infty}^{0} \mathrm{f}\left(\tilde{\mathrm{y}}_{\mathrm{NPV}, 0}\right) \tilde{\mathrm{y}}_{\mathrm{NPV}, 0}
$$


The expected value, which is the predicted outcome of a variable, is a key aspect of how a probability distribution is characterized. The expected values of NPV and IRR were calculated by adding up the resultant values of each iteration weighted by their individual probability of occurrence, as given by Eq. $16[80]$.

$$
\mathrm{E}[\mathrm{X}]=\sum_{\mathrm{i}=0}^{\mathrm{N}} \mathrm{X}_{\mathrm{i}} \mathrm{pdf}\left(\mathrm{X}_{\mathrm{i}}\right)
$$

where $\mathrm{N}$ denotes the number of possible outcomes of the random variable $\mathrm{X}$, that is NPV or IRR, and pdf is the probability density function of the variable. The maximum potential loss of the investment with a $95 \%$ confidence level (VaR) was then calculated by getting the $5^{\text {th }}$ percentile of the NPV distribution function.

\section{Results and Discussion}

Refrigeration systems ranging in milk cooling capacities from 100 to 1000 litres were considered. The technical results of various stand-alone renewable energy based VCRS and VARS systems are shown in Tables. 4 and 5 respectively.

\section{Table 4}

Technical results of renewable powered VCRS configurations at various cooling capacities in litres

\begin{tabular}{|c|c|c|c|c|c|c|c|c|c|c|c|}
\hline \multicolumn{3}{|c|}{ System description } & \multicolumn{9}{|c|}{ Values } \\
\hline & Parameter & 100 & 200 & 300 & 400 & 500 & 600 & 700 & 800 & 900 & 1000 \\
\hline VCRS & Power consumption $\left(\mathrm{kW}_{\mathrm{e}}\right)$ & 0.24 & 0.48 & 0.72 & 0.95 & 1.19 & 1.43 & 1.67 & 1.91 & 2.14 & 2.38 \\
\hline PV system & $\begin{array}{l}\mathrm{PV} \text { array size }\left(\mathrm{kW}_{\mathrm{p}}\right) \\
\text { Energy storage capacity }(\mathrm{kWh}) \\
\text { Quantity of batteries } \\
\text { Inverter size }\left(\mathrm{kW}_{\mathrm{p}}\right)\end{array}$ & $\begin{array}{l}2.1 \\
29 \\
12 \\
0.3\end{array}$ & $\begin{array}{l}3.9 \\
57 \\
24 \\
0.6\end{array}$ & $\begin{array}{l}5.7 \\
86 \\
34 \\
0.89\end{array}$ & $\begin{array}{l}7.5 \\
114 \\
46 \\
1.19\end{array}$ & $\begin{array}{l}9.4 \\
143 \\
56 \\
1.49\end{array}$ & $\begin{array}{l}11.2 \\
172 \\
68 \\
1.79\end{array}$ & $\begin{array}{l}13 \\
200 \\
80 \\
2.08\end{array}$ & $\begin{array}{l}14.8 \\
229 \\
90 \\
2.38\end{array}$ & $\begin{array}{l}16.6 \\
257 \\
102 \\
2.68\end{array}$ & $\begin{array}{l}18.5 \\
286 \\
112 \\
2.98\end{array}$ \\
\hline $\begin{array}{l}\text { Wind } \\
\text { turbine } \\
\text { system }\end{array}$ & $\begin{array}{l}\text { Wind farm size }\left(\mathrm{kW}_{\mathrm{p}}\right) \\
\text { Energy storage capacity }(\mathrm{kWh}) \\
\text { Quantity of batteries } \\
\text { Inverter size }(\mathrm{kW})\end{array}$ & $\begin{array}{l}7.5 \\
29 \\
12 \\
0.3\end{array}$ & $\begin{array}{l}7.5 \\
57 \\
24 \\
0.6\end{array}$ & $\begin{array}{l}15 \\
86 \\
36 \\
0.89\end{array}$ & $\begin{array}{l}15 \\
114 \\
48 \\
1.19\end{array}$ & $\begin{array}{l}22.5 \\
143 \\
56 \\
1.49\end{array}$ & $\begin{array}{l}22.5 \\
172 \\
68 \\
1.79\end{array}$ & $\begin{array}{l}30 \\
200 \\
80 \\
2.08\end{array}$ & $\begin{array}{l}30 \\
229 \\
76 \\
2.38\end{array}$ & $\begin{array}{l}37.5 \\
257 \\
88 \\
2.68\end{array}$ & $\begin{array}{l}37.5 \\
286 \\
96 \\
2.98\end{array}$ \\
\hline $\begin{array}{l}\text { Biogas } \\
\text { system }\end{array}$ & $\begin{array}{l}\text { ICE rated capacity }\left(\mathrm{kW}_{\mathrm{e}}\right) \\
\text { ICE efficiency }(\%) \\
\text { Volume of digester }\left(\mathrm{m}^{3}\right) \\
\text { Quantity of fuel (ton/day) }\end{array}$ & $\begin{array}{l}1.5 \\
13 \\
24 \\
0.9\end{array}$ & $\begin{array}{l}1.5 \\
13 \\
47 \\
1.9\end{array}$ & $\begin{array}{l}1.5 \\
13 \\
70 \\
2.8\end{array}$ & $\begin{array}{l}1.5 \\
13 \\
94 \\
3.8\end{array}$ & $\begin{array}{l}1.5 \\
13 \\
117 \\
4.7\end{array}$ & $\begin{array}{l}1.5 \\
13 \\
140 \\
5.7\end{array}$ & $\begin{array}{l}3 \\
13 \\
157 \\
6.3\end{array}$ & $\begin{array}{l}3 \\
13 \\
179 \\
7.2\end{array}$ & $\begin{array}{l}3 \\
13 \\
201 \\
8.2\end{array}$ & $\begin{array}{l}3 \\
13 \\
224 \\
9.1\end{array}$ \\
\hline $\begin{array}{l}\text { Biomass } \\
\text { system }\end{array}$ & $\begin{array}{l}\text { Gasifier, ICE size (kWe) } \\
\text { Quantity of fuel (ton/day) } \\
\text { System efficiency (\%) }\end{array}$ & $\begin{array}{l}10 \\
0.34 \\
14.6 \\
\end{array}$ & $\begin{array}{l}10 \\
0.68 \\
14.6 \\
\end{array}$ & $\begin{array}{l}10 \\
0.1 \\
14.6\end{array}$ & $\begin{array}{l}10 \\
0.14 \\
14.6 \\
\end{array}$ & $\begin{array}{l}10 \\
0.17 \\
14.6 \\
\end{array}$ & $\begin{array}{l}10 \\
0.21 \\
14.6 \\
\end{array}$ & $\begin{array}{l}10 \\
0.24 \\
14.6 \\
\end{array}$ & $\begin{array}{l}10 \\
0.27 \\
14.6 \\
\end{array}$ & $\begin{array}{l}10 \\
0.31 \\
14.6 \\
\end{array}$ & $\begin{array}{l}10 \\
0.34 \\
14.6 \\
\end{array}$ \\
\hline
\end{tabular}

Table 5

Technical results of renewable powered VARS configurations at various capacities

\begin{tabular}{|c|c|c|c|c|c|c|c|c|c|c|c|}
\hline \multirow[t]{2}{*}{ System description } & 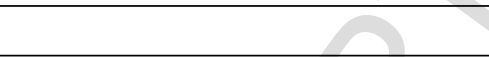 & \multicolumn{10}{|c|}{ Values } \\
\hline & Parameters & 100 & 200 & 300 & 400 & 500 & 600 & 700 & 800 & 900 & 1000 \\
\hline VARS & Size in Rtons $\left(1 \mathrm{Rton} \sim 3.5 \mathrm{~kW}_{\mathrm{th}}\right)$ & 4.4 & 8.9 & 13.3 & 17.8 & 22.2 & 26.6 & 31.1 & 35.5 & 40 & 44.4 \\
\hline \multicolumn{2}{|c|}{ Solar thermal system Solar collector size $\left(\mathrm{m}^{2}\right)$} & 17.9 & 34.6 & 51.2 & 67.8 & 84.4 & 101 & 117.6 & 134.2 & 150.8 & 167.4 \\
\hline \multirow{2}{*}{ Biogas system } & Volume of digester $\left(\mathrm{m}^{3}\right)$ & 51 & 100 & 149 & 199 & 248 & 298 & 348 & 397 & 447 & 496 \\
\hline & Quantity of fuel (ton/day) & 1 & 2 & 3 & 4 & 5 & 6 & 7 & 8 & 9 & 10 \\
\hline \multirow{2}{*}{ Biomass system } & Gasifier, boiler size $\left(\mathrm{kW}_{\mathrm{th}}\right)$ & 8.6 & 17.2 & 25.8 & 34.4 & 43.0 & 51.6 & 60.1 & 68.7 & 77.3 & 85.9 \\
\hline & Quantity of fuel (kg/day) & 24 & 48 & 73 & 97 & 121 & 145 & 170 & 194 & 218 & 242 \\
\hline
\end{tabular}

\subsection{Economic Analysis}

Cost data reported in years prior to 2017 were indexed using Tanzania's inflation rate averaged over 10 years [81]. Replacement and end of project salvage costs based on the technology lifetimes (Table 1) reported by the manufacturer were considered. The economic performance of each stand-alone system, using initial base case values discussed in the previous chapter, is presented in terms of the NPV and IRR and can be seen in Figure 11 and 12 respectively. 


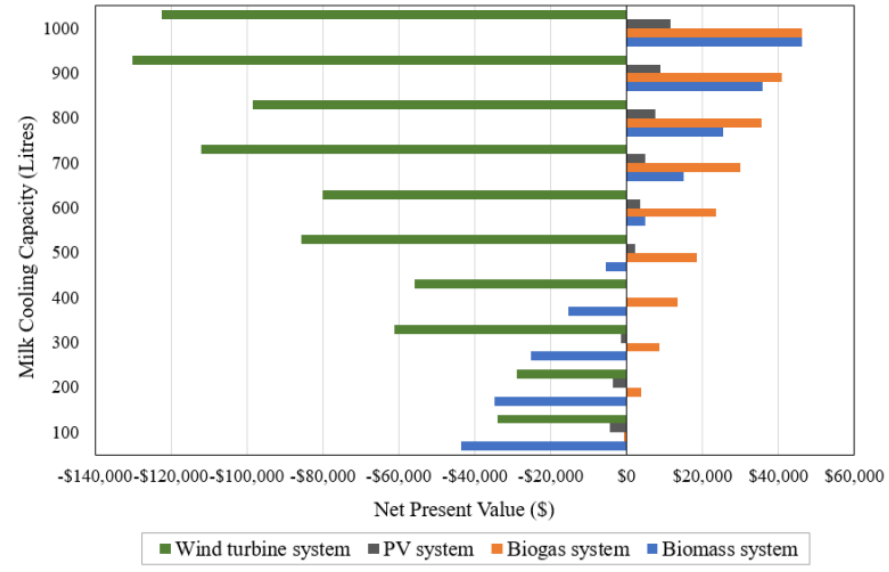

(a)

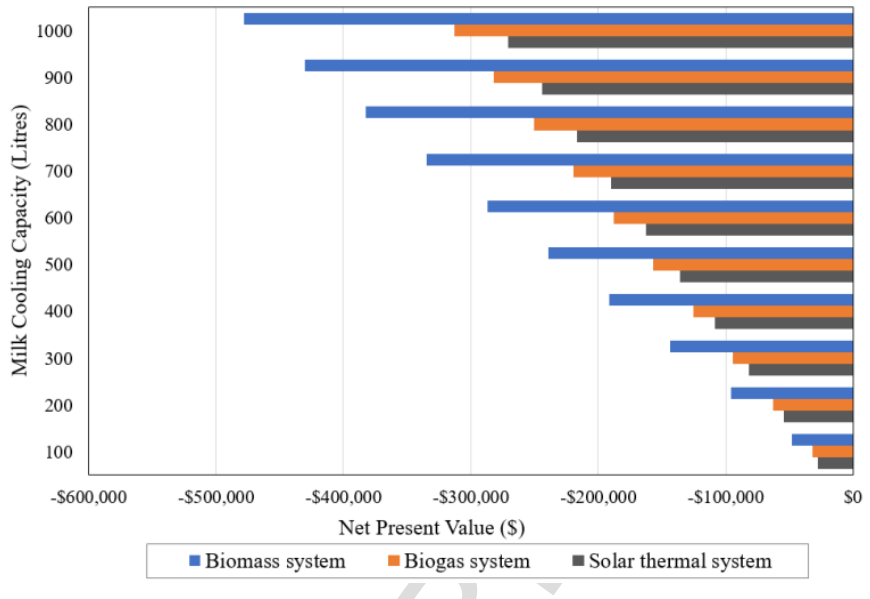

(b)

Fig. 11. NPVs of different (a) VCRS (b) VARS systems at various cooling capacities
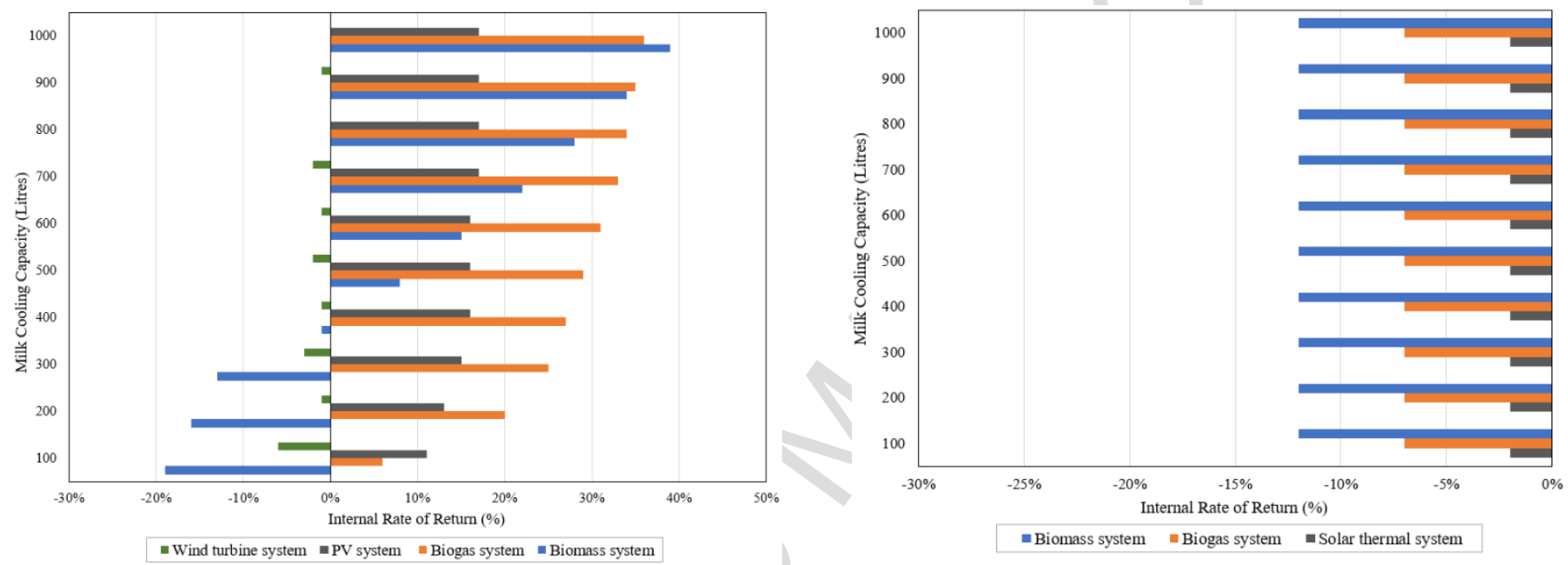

Fig 12. IRR of different (a) VCRS (b) VARS systems at various cooling capacities

Considering the potential to bulk, cool and sell approximately 660 litres of milk per day, at 300 litres cooling capacity (two milking sessions a day), the biogas VCRS system was predicted to be the only profitable system, with an NPV of about $\$ 9,094$. Given that private mini-grid operators in Africa commonly expect a project IRR of at least $12 \%$ [82], the system is observed to have a commercially viable IRR of $25 \%$. In terms of economies of scale, the biogas, PV and biomass VCRS configurations greater than 100, 400 and 500 litres respectively, are observed to increase in potential profitability with increasing capacity, reaching an NPV of about $\$ 46,000$ and an IRR of $39 \%$. The wind turbine system is observed to be highly unprofitable for all VCRS system sizes, due to the high investment cost. Similarly, none of the VARS systems is predicted to have a positive NPV for any system cooling capacity. The high cost of absorption chillers has been identified as a key constraint impeding their adoption, especially in developing counties. However, the absorption chiller market is expected to grow over the next 10 years, which may in turn drive down the cost [83]. The ISAAC solar powered icemaker pilot programme, which was funded by the World Bank installed three of these technologies, which are based on the ammonia-water VARS in Kenya for milk cooling but it has not been replicated in the region [68].

While there are currently no off-grid biogas-powered bulk milk cooling systems in operation in East Africa, there are examples of such systems that have been successfully implemented in other developing countries. Two 500-litre and two 1000-litre biogas-powered milk cooling plants have been successfully implemented in Pakistan by Winrock International, Pakistan. Three of the biogas plants were installed in farms with about 100 cows each, while the other was installed and is operated at a community level where each villager owns a small number of cows [84]. A 1000-litre bulk milk cooling system powered by biogas generated from cow dung has also been successfully implemented in Ghazipur, India by New Leaf Dynamic Technology [85].

The average gross monthly income from milk sales per household in the target community was reported to be Tzs $58,918(\$ 35.87)$. With the opportunity to store the milk that is being wasted, which is on average 2.9 litres per day per household, the potential incremental gross monthly income per household at the farm-gate price was calculated to be Tzs 45,778 (\$27.87), a 78\% increase.

\subsection{Sensitivity Analysis}


Uncertainties in any techno-economic analyses are inevitable as models can only be an estimation of the physical system. Initial investment and operation and maintenance (O\&M) costs, discount rate, fuel costs and the biogas specific yield $\left(\mathrm{m}^{3} / \mathrm{kg}\right)$ have all been identified previously [86] [87] as being likely to have an impact on the economic success of off-grid biogas systems. In terms of revenue, the prices of agricultural commodities including milk are highly uncertain due to several external factors such as unforeseen variations in demand and yield, and as such net revenues from milk sales (\$/litre) and quantity of daily milk cooled were selected as sensitivity analysis parameters. The sensitivity characteristic models for the NPV and IRR of the 300-litre biogas system is shown in Fig. 13.

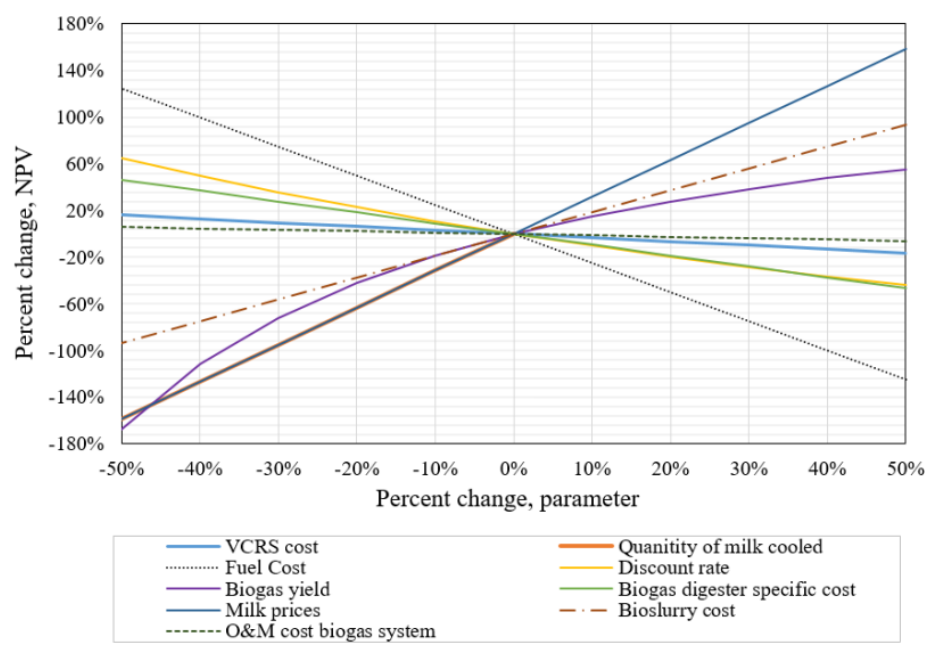

(b)

(a)

Fig. 13. Sensitivity characteristic model of the project (a) net present value (b) internal rate of return

The NPV of the system is seen to be most sensitive to variations in milk prices, quantity of daily milk cooled and bio-slurry cost, which determine the net income generated and least sensitive to the O\&M biogas system cost, and VCRS investment cost. A 50\% increase in milk prices and bio-slurry cost causes a $158 \%$ and $94 \%$ increase in the NPV respectively, whilst a $50 \%$ decrease in the quantity of daily milk cooled and biogas specific yield causes a $158 \%$ and $168 \%$ decrease in the NPV respectively. A $50 \%$ decrease in discount rate and fuel cost resulted in a $65 \%$ and $125 \%$ increase in the NPV respectively. In addition, the IRR is also seen to be sensitive to a decrease in the biogas digester specific cost, resulting in an IRR of $52 \%$ for a $50 \%$ change in its value. Study [86] found the NPV of a small-scale biogas plant in Bolivia to be most sensitive to the fuel price, investment cost, and the electricity price, but less sensitive the biogas yield. Work [87] also found the NPV of a biogas project in Brazil to be highly sensitive to the electricity price, as well as the discount rate. Based on the results of the present study, seven parameters were selected for further analysis as part of a due diligence analysis.

\subsection{Risk Analysis}

The annual average farm gate price per liter of milk received by farmers who were surveyed in Lushoto district by the MoreMilkIT project, ranged between Tzs 476 - 1000 as shown in Fig. 14 [17]. A study [20], which examined the effects of season and location on cattle milk produced and producer milk prices in the Tanga and Morogoro regions of Tanzania reported the average producer milk price in Lushoto district as Tsh 490.55/liter with a standard deviation of Tsh 9.02/liter. Similarly, data collected by TechnoServe, a nongovernmental organization (NGO) that works with farmers, cooperatives, suppliers and processors in Tanzania, noted that the farm gate price per liter of milk sold by producers to milk collection centers ranged between Tzs $550-750$ over the same time period. The factory gate price per liter of milk sold by the Milk Collection Center is usually set through negotiations with the processing plants. An average factory gate price of Tzs 650 in milk collection centers in Tanga was reported in 2012. [88].

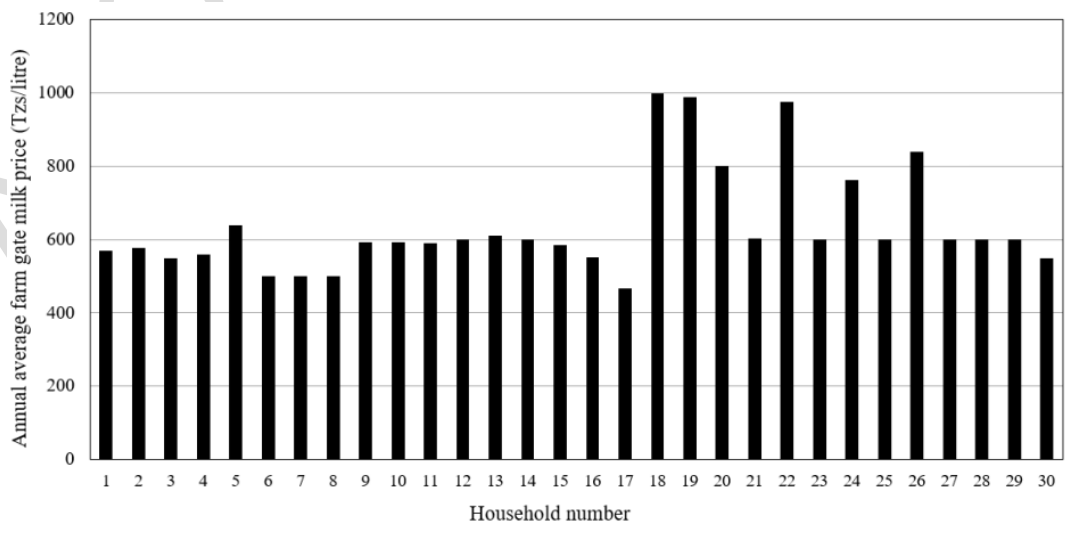

Fig 14. Annual average farm gate milk prices (MoreMilkIT data, 2014) 
The fluctuations in milk supply caused by variation in weather conditions and animal health status can be significant in any given year. However, the monthly average quantity of milk produced by household per day in Lushoto district was observed to have an approximate uniform distribution with a mean of 4.1 litres/day and standard deviation of 2.24 litres/day, with only a slight decline in November and December (Fig 15.), which could be attributed to the zero-grazing feeding system where farmers have access to supplementary feeds [20].

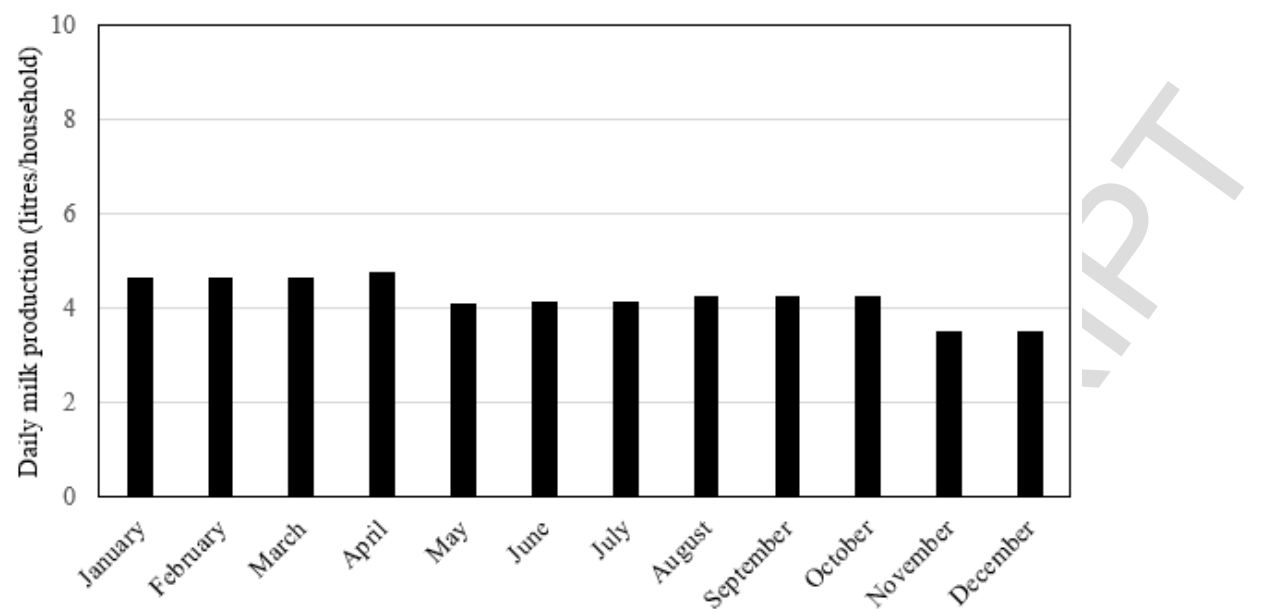

Fig. 15. Average daily milk production in liter per household throughout the year in Lushoto

A study [89], which analyzed data collected from households in northern Tanzania with bio-digesters installed through the TDBP reported a bio-digester installed cost ranging between $\$ 73 / \mathrm{m}^{3}$ and $\$ 125 / \mathrm{m}^{3}$, while study [90], which analyzed the performance of a biogas plant installed in north-eastern Tanzania reported an actual average biogas yield of $0.27 \mathrm{~m}^{3} / \mathrm{kgVS}$, with a standard deviation (SD) of $+/-0.035 \mathrm{~m}^{3} / \mathrm{kgVS}$.

A study [72] that examined crop farmers' willingness to pay for bio-slurry as organic fertilizer for crop production showed that the farmers were willing to pay $12 \%$ more for organic fertilizer than what they typically spend on inorganic fertilizer. As such, the price and quantity of inorganic fertilizer applied per hectare (ha) were used as a proxy for the cost of bio-slurry. Application of approximately 4 tons/ha of composted bio-slurry is recommended [60], replacing an average of $26 \mathrm{~kg} / \mathrm{ha}$ of inorganic fertilizer, which costs $\$ 37$ per 50 $\mathrm{kg}$ bag [91]. The average cost of composted bio-slurry was therefore calculated to be $\$ 5.39 /$ ton.

The probability distribution parameters utilized in the MC analysis for a 300-litre biogas system configuration are presented in Table 6. A normal probability distribution was used for uncertain parameters for which a large sample of data was available, while a triangular distribution was used for parameters where only limited sample data was available.

Table 6

Probability distribution parameters of uncertain system parameters

\begin{tabular}{llll}
\hline Parameter & Distribution & Parameters & Reference \\
\hline Biogas system investment cost $\left(\$ / \mathrm{m}^{3}\right)$ & Triangular & Min:73, Mode: 81, Max: 125 & {$[89]$} \\
Farm gate milk price (Tsh/liter) & Normal & Mean: 490.55, SD: 9.02 & {$[20]$} \\
Factory gate milk price (Tsh/liter) & Triangular & Min: 550, Mode: 650, Max: 750 & {$[92]$} \\
Quantity of milk produced per household (litres/day) & Normal & Mean: 4.1, SD: 2.24 & {$[20]$} \\
Fuel cost, cow manure $(\mathrm{Tsh} / \mathrm{kg})$ & Triangular & Min:15, Mode: 20, Max: 40 & {$[72]$} \\
Composted bio-slurry cost $(\$ / \mathrm{ton})$ & Normal & Mean: 5.39, SD: 3.24 & {$[72]$} \\
Biogas specific yield $\left(\mathrm{m}^{3} / \mathrm{kgVS}\right)$ & Normal & Mean: 0.27, SD: 0.035 & {$[90]$} \\
Discount rate $(\%)$ & Triangular & Min: 4, Mode: 12, Max; 22 & {$[93]$} \\
\hline
\end{tabular}

The results of the MC analysis indicate that the 300-litre biogas powered milk cooling system has an expected risk-adjusted NPV of $\$ 17,319$, with an expected IRR of $57 \%$, which projects the system to be profitable, achieving an $82 \%$ probability of a positive NPV and $92 \%$ probability of an IRR $>12 \%$ as shown in Fig. 16. This compares to the initial NPV of $\$ 9,094$ and IRR of $25 \%$. The maximum potential loss at a $95 \%$ confidence level is observed to be approximately $-\$ 31,300$. 

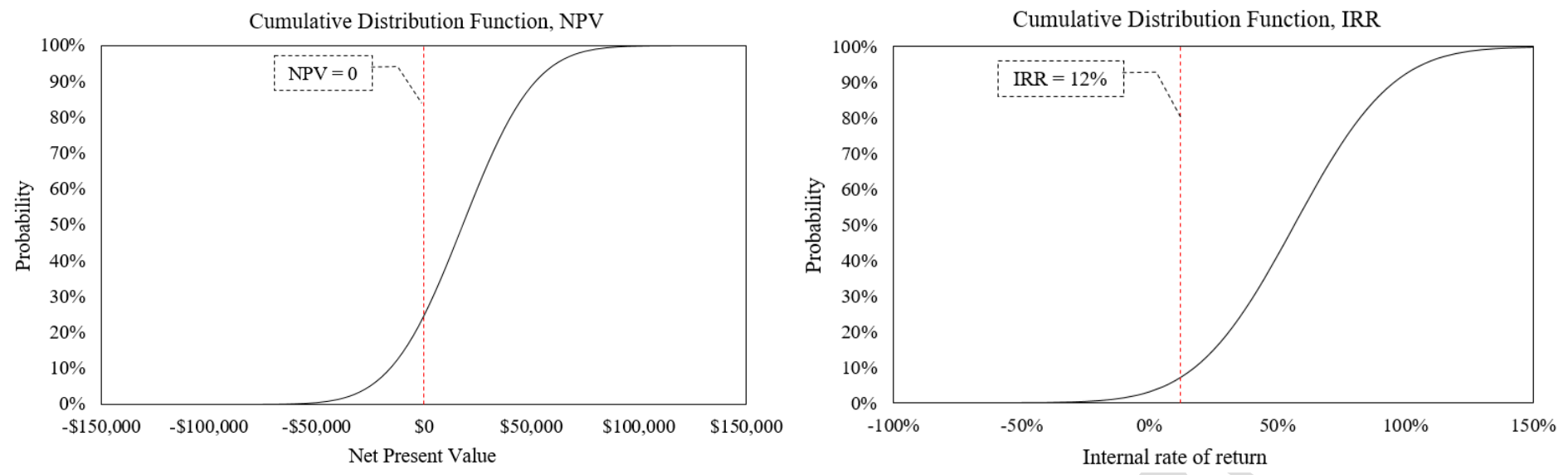

Fig. 16. Cumulative distribution function plots of NPV and IRR

The expected NPV is observed to be greater than the baseline NPV for the $100-500$ liter biogas systems, reaching an expected NPV of about $\$ 22,000$, as shown in Fig 17. The quantity of milk cooled per day, which was found to have a significant impact on the economic performance, could be the reason why systems above 600 litres are observed to have declining economic performance, with the 900 and 1000-litre systems projected to be unprofitable.

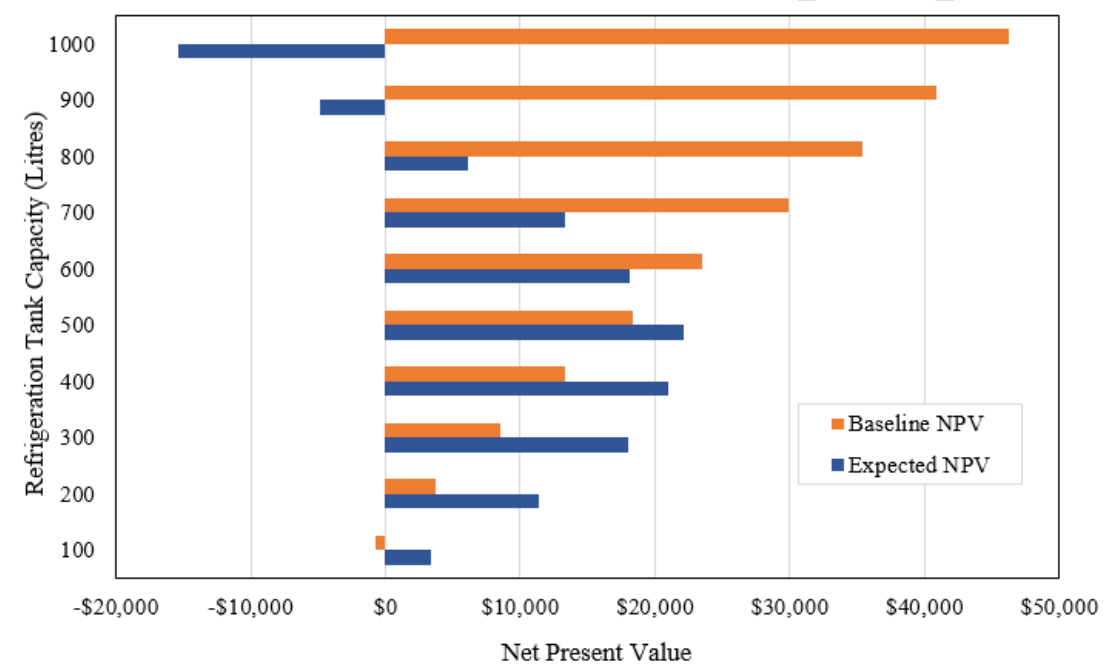

Fig 17. Change in impact of risk factors on system NPV with changing system capacity

Initially, the probability of a positive NPV is observed to increase with increasing cooling capacity, peak at 300 litres and then decrease up to a $41 \%$ probability of economic success for the 1000-litre system, as shown in Fig 18.

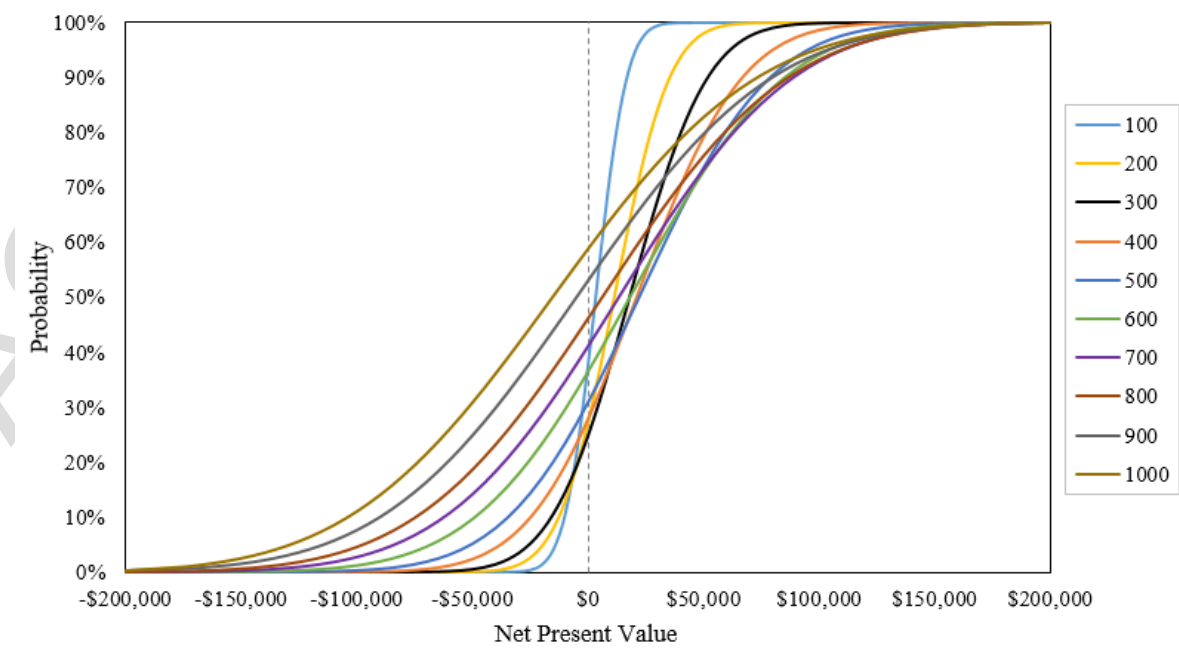

Fig 18. Cumulative distribution functions for NPV at various cooling capacities 


\subsubsection{Mitigating Risks and Challenges}

An integrated risk mitigation strategy could include government financial support, as well as guarantee and insurance arrangements with parties involved in the construction and operation of the project [94]. Stable policy support is desirable, for example to mitigate risk of fluctuations in the capital costs of the system, which was determined to be the greatest risk factor for the project. The TDBP, currently in its second phase, offers micro-credit schemes, training sessions and technology support to promote the large-scale dissemination of domestic biogas systems in rural communities across the country [95]. The Rural Energy Agency offers Tsh 240,000 ( \$100) subsidy per biogas system installation [96]. Establishing long-term milk supply and milk purchase agreements with farmers and milk processing factories can help in mitigating the risk of volatile milk prices. However, this could potentially result in lower net revenue from milk sales based on price fluctuations in the market. A 'contract-for-difference' (CFD) agreement could also evolve as a solution for managing fluctuations in milk prices, whereby the buyer or seller is obligated to pay the other the difference between the milk's current price and its price at the time of the contract (if the difference is positive, the seller pays the buyer, if it is negative, the buyer pays). However, CFDs are currently not available in any of the East African countries [97]. Similar purchase agreements could be made with the dairy farmers for the supply of manure to mitigate the uncertainty in fuel availability and cost, and with crop farmers for the purchase of composted bio-slurry as fertilizer for their crops. The quantity of milk produced is also a risk factor, as operating at less than full capacity results in lower net revenue, which has a high impact on financial viability. To mitigate this risk, added services (such as mobile phone charging stations or solar lantern recharging) could be set up to supplement the net income generated as evidenced in [98].

Other challenges that may be encountered in establishing a biogas-powered milk chilling plant in the case study area include difficulty finding skilled workers to maintain and operate the plant who are willing to work in a remote area, and reliable supply of spare parts. The challenge of skilled workers can be overcome by partnering with institutions, such as The Centre for Agricultural Mechanization and Rural Technology [99], that can offer technical training to the local youths, as part of the general capacity building program within the hub, thereby creating job opportunities for them, as well as business training for managers of the chilling hub. Availability of spare parts from major urban centers, such as Dar es Salaam, which are far away, may be enhanced through contractual arrangements with vendors and suppliers. The role of Information and Communication Technology, ICT, is underscored in this process, and will be enhanced in the hub.

\section{Conclusions}

The financial viability and risks associated with investing in an off-grid renewable energy based milk cooling system has been assessed in this study, with the aim of addressing the challenges of high milk spoilage and limited market access among dairy farmers in the rural areas of East Africa. The study found that an average 3 litres of milk per household per day is wasted in the study area, suggesting that there is potential to bulk, cool and sell as much as 600 litres of milk per day in the community. A biogas powered vapor compression refrigeration system was determined to be the most economically viable solution, resulting in a net present value of $\$ 9,094$ and internal rate of return of $25 \%$ for a 300 -litre cooling tank capacity. The system was also determined to be scalable; exhibiting increased economic performance with an increase in the cooling capacity for large dairy concerns. With the opportunity to store the milk that was being wasted, the system could offer a projected increase in farmers' monthly income of at least $78 \%$.

The economic performance of the system was found to very sensitive to fuel cost, price of bio-slurry for sale, biogas specific yield, and the milk quantity and prices. The results of the due-diligence process determined that despite the risk factors, the system has an $82 \%$ probability of a positive NPV. However, specific risk factors significantly reduce system profitability with increasing cooling capacity. If strategies to mitigate technical, economic and policy risks are implemented so as to increase the probability of economic viability, biogas powered vapor compression milk cooling systems could offer small-scale off-grid dairy farmers a significant opportunity to grow their businesses, increase their income and thus improve their standards of living. As such, there is an opportunity for future empirical research, to measure the causal effect of a community biogas milk cooling system on selected indicators of improved living standards, such as measures of income, health and education.

\section{Acknowledgements}

The authors would like to thank Amos Omore, Tanzania Country Representative, International Livestock Research Institute (ILRI), Edgar Twine, Scientist at ILRI, Tanzania and Alice Njehu, Research Assistant at ILRI, Nairobi for providing access to the MoreMilkiT project data used in this study.

\section{References}

[1] S. Bingi and F. Tondel, "Recent developments in the dairy sector in Eastern Africa," European Centre for Development and Policy Management, Maastricht, The Netherlands, 2015.

[2] S. Wambugu, L. Kirimi and J. Opiyo, "Productivity trends and Performance of Dairy Farming in Kenya," Tegemeo Institute of Agricultural Policy and Development, Nairobi, 2011.

[3] TechnoServe Uganda, "The Dairy Value Chain in Uganda," East Africa Dairy Development, Kampala, 2008.

[4] A. Njombe, Y. Msanga, N. Mbwambo and N. Makembe, "The Tanzania Dairy Industry: Status, Opportunities and Prospects," in 7th African Dairy Conference and Exhibition, Dar es Salaam, 2011.

[5] E. Twine and A. Omore, "Securing more income for marginalized communites in Tanzania through dairy market hubs," MoreMilkiT project, Tanzania, 2015.

[6] A. Omore, "More milk in Tanzania (MoreMilkiT)," International Livestock Research Institute (ILRI), Nairobi, 2013. 
[7] G. Kruse, "The Chilling Hub Model and Social Capital in Dairy Value Chain Development," Heifer International - Kenya, Nairobi, 2012.

[8] J. Gustavsson, C. Cederberg, U. Sonesson, R. Van Otterdijk and A. Meybeck, "Global food Losses and Food Waste," Food and Agricultural Organization (FAO), Rome, 2011.

[9] A. Cherif and A. Dhouib, "Dynamic modelling and simulation of a photovoltaic refrigeration plant," Renewable Energy, vol. 26, pp. 143-153, 2002.

[10] V. Torres-Toledo, K. Meissner, A. Coronas and J. Müller, "Performance characterisation of a small milk cooling system with ice storage for PV applications," International Journal of Refrigeration, vol. 60, pp. 81-91, 2015.

[11] A. Modi, A. Chaudhuri, B. Vijay and J. Mathur, "Performance analysis of a solar photovoltaic operated domestic refrigerator," Applied Energy, vol. 86, pp. 2583$2591,2009$.

[12] M. Edwin and J. Sekhar, "Techno-economic studies on hybrid energy based cooling system for milk preservation in isolated regions," Energy Conversion and Management, vol. 86, pp. 1023-1030, 2014.

[13] A. Chauhan and R. Saini, "Techno-economic feasibility study on Integrated Renewable Energy System for an isolated community of India," Renewable and Sustainable Energy Reviews, vol. 59, pp. 388 - 405, 2016.

[14] S. T. Bahta, "Design and Analyzing of an Off-Grid Hybrid Renewable Energy System to Supply Electricity for Rural Areas," KTH Industrial Engineering and Management, Stockholm, 2013.

[15] S. Tomosk, J. Haysom and D. Wright, "Quantifying economic risk in photovoltaic power projects," Renewable Energy, vol. 109, pp. 422-433, 2017.

[16] E. P. José da Silva , J. T. Pinho and M. A. B. Galhardo, "Methodology of risk analysis by Monte Carlo Method applied to power generation with renewable energy," Renewable Energy, vol. 69, pp. 347-355, 2014.

[17] ILRI, "The MoremilkiT project: Baseline report," International Livestock Research Institute, Nairobi, 2014.

[18] W. Luoga, L. R. Kurwijila, D. Nyange and R. Ryoba, "Determinants of Access and Participation of Smallholder Farmers in Dairy Input and Output Markets in Tanzania: A Case study of Rungwe District," Tanzania Journal of Agricultural Sciences, vol. 8, no. 1, pp. 57 - 66, 2007.

[19] Tanzania National Bureau of Statistics, "Population Distribution of Dodoma Region by District, Ward and Village/Mtaa; 2012 PHC," Tanzania National Bureau of Statistics, 2012. [Online]. Available: http://ihi.eprints.org/2168/1/Village_Statistics.pdf. [Accessed 12 March 2016].

[20] F. Wassena, W. Mangesho, A. Chawala, G. Laswai, J. Bwire, A. Kimambo, B. Lukuyu, G. Sikumba and B. Maass, "Effects of season and location on cattle milk produced and producer milk prices in selected villages of Tanga and Morogoro Regions, Tanzania," Livestock Research for Rural Development, vol. 27, no. 10, 2015.

[21] The Africa Enterprise Challenge Fund (AECF), "Tanga Fresh,” The Africa Enterprise Challenge Fund (AECF), Nairobi, 2011.

[22] Atmospheric Science Data Center, "Surface meteorology and Solar Energy," National Aeronautics and Space Administration (NASA), 12 April 2016. [Online]. Available: https://eosweb.larc.nasa.gov/sse/. [Accessed 16 June 2016].

[23] R. Alfayo and C. B. S. Uiso, "Global solar radiation distribution and available solar energy potential in Tanzania," Physica Scripta, vol. T97, pp. 91 - 98, 2002.

[24] ESMAP, "Renewable Energy Resource Mapping in Tanzania," The World Bank, 2013. [Online]. Available: https://www.esmap.org/re_mapping_TNZ. [Accessed 16 June 2016].

[25] J. Terrapon-Pfaff, "Linking Energy- and Land-Use Systems: Energy Potentials and Environmental Risks of Using Agricultural Residues in Tanzania," Sustainability, vol. 4, pp. 278-293, 2012.

[26] Sao Hill Industries, "Production and delivery of wood briquettes and other processed waste," Sao Hill Industres Company Ltd, 2017. [Online]. Available: http://www.saohill.com/news-and-events.html. [Accessed 21 November 2017].

[27] Department of Agriculture and Fisheries, "Manure production data," Queensland Government, 1 July 2011. [Online]. Available: https://www.daf.qld.gov.au/environment/intensive-livestock/cattle-feedlots/managing-environmental-impacts/manure-production-data. [Accessed 22 June 2016].

[28] United States Department of Agriculture, “Animal Manure Management," United States Department of Agriculture, 7 December 1995. [Online]. Available: https://www.nrcs.usda.gov/wps/portal/nrcs/detail/national/technical/nra/?\&cid=nrcs143_014211\#collected. [Accessed 25 April 2017].

[29] SimGas Tanzania, Ltd., "Gesi Shamba," SimGas Tanzania, Ltd., 2012. [Online]. Available: http://www.simgas.com/products/gesi-shamba/item33. [Accessed 23 6 2016].

[30] E. Ng'wandu, L. Shila and F. ter Heegde, "Programme Implementation Document: Tanzania Domestic Biogas Programme,” Tanzania Domestic Biogas Programme, Dar es Salaam, 2009.

[31] C. Lyamchai, P. Yanda, G. Sayula and P. Kristjanson, "Summary of Baseline Household Survey. Results: Lushoto, Tanzania," CGIAR Research Program on Climate Change, Agriculture and Food Security (CCAFS), Copenhagen, 2011.

[32] R. Carnegie, D. Gotham, D. Nderitu and P. Preckel, "Utility Scale Energy Storage Systems," State Utility Forecasting Group, West Lafayette, 2013.

[33] P. Moseley and J. Garche, Electrochemical Energy Storage for Renewable Sources and Grid Balancing, Oxford: Elsevier, 2015.

[34] A. Miskam, Z. A. Zainal and I. M. Yusof, "Characterization of Sawdust Residues for Cyclone Gasifier," Journal of Applied Sciences, vol. 9, pp. $2294-2300,2009$.

[35] J. Mutyaba, An assessment of the potential for using gasification technologies for thermal applications in Uganda's small-scale agro-industries, Stockholm: Royal Institute of Technology, 2014.

[36] N. Nwokolo, S. Mamphweli, E. Meyer and S. Tangwe, "Electrical performance evaluation of Johansson biomass gasifier system coupled to a $150 \mathrm{KVA}$ generator," Renewable Energy, vol. 71, pp. 695-700, 2014.

[37] T. Amon, B. Amon, V. Kryvoruchko, W. Zollitsch, C. Mayer and L. Gruber, "Biogas production from maize and dairy cattle manure--Influence of biomass composition on the methane yield," Agriculture, Ecosystems \& Environment, vol. 118, p. 173-182, 2007.

[38] International Renewable Energy Agency, "Biomass for Power Generation," International Renewable Energy Agency , Bonn, 2012.

[39] Powerpoint Reliable Energy Solutions, "Inverters," PowerPoint Systems (E.A) Ltd, 2016. [Online]. Available: http://www.powerpoint.co.ke/index.php/onlineshop/buy-goods/inverters. [Accessed 22 June 2016].

[40] Trojan battery company, "Solar True Deep-Cycle AGM Data Sheet," Trojan battery company, 2017. [Online]. Available: http://www.trojanbattery.com/pdf/SAGM_12_205_AGM_DS.pdf. [Accessed 12 December 2017].

[41] T. Buchholz, I. Da Silva and J. Furtado, "Power from wood gasifiers in Uganda: a $250 \mathrm{~kW}$ and $10 \mathrm{~kW}$ case study," Institution of Civil Engineers - Energy, vol. 165 , no. 4, pp. 181-196, 2015.

[42] L. I. Chaves, J. S. Marcelo, S. N. Melegaride Souza, S. Deonir, R. A. Helton, C. E. C. Nogueira and E. Pires Frigo, "Small-scale power generation analysis: Downdraft gasifier coupled to engine generator set," Renewable and Sustainable Energy Reviews, vol. 58, pp. 491-498, 2016.

[43] Shenzhen Puxin Technology Co., Ltd., "Biogas Generators," Shenzhen Puxin Technology Co., Ltd., 2016. [Online]. Available: https://puxinbiogas.en.alibaba.com/productgrouplist-802190307/Biogas_Generators.html. [Accessed 22 June 2016].

[44] Canadian Solar Inc, “CS6P-250|255|260P e Product Datasheet," December 2014. [Online]. Available: https://d1819pwkf4ncw.cloudfront.net/files/documents/datasheetcs6p250255260p-270018.pdf. [Accessed 22 June 2016].

[45] Bergey Windpower Co, "Retail Price List: WInd Turbines," 1 October 2013. [Online]. Available: http://bergey.com/documents/2013/10/bwc-retail-price-list-1001-13.pdf. [Accessed 22 June 2016]. 
[46] Sustainable Production through Innovation in SMEs, "SOLARICE® Ammonia Absorption Cooling," Sustainable projects GmbH, [Online]. Available: http://spinproject.eu/index.php?node_id=58.30\&lang_id=1. [Accessed 12 November 2017].

[47] IRENA, "Solar Heating and Cooling for Residential Applications," IRENA, Bonn, 2015.

[48] S. Dasappa, "Potential of biomass energy for electricity generation in sub-Saharan Africa," Energy for Sustainable Development, vol. 15, pp. $203-213$, 2011.

[49] T. G. Berhe, R. G. Tesfahuney, G. A. Desta and L. S. Mekonnen, "Biogas Plant Distribution for Rural Household Sustainable Energy Supply in Africa," Energy and Policy Research, vol. 4, no. 1, pp. 10-20, 2017.

[50] F. Moffat, S. Khanal, A. Bennett, T. B. Thapa and S. M. George, "Technical and investment guidelines for milk cooling centres," Food and Agriculture Organization og the United Nations, Rome, 2016.

[51] P. G. Nikhil and D. Subhakar, "An improved algorithm for photovoltaic system sizing," Energy Procedia, vol. 14, p. 1134 - $1142,2012$.

[52] Trojan Battery Company, "Battery Sizing Guidelines for Renewable Energy and Backup Power Applications," 2013. [Online]. Available: http://www.trojanbattery.com/pdf/TRJN0168_BattSizeGuideFL.pdf. [Accessed 12 December 2017].

[53] G. Albright, J. Edie and S. Al-Halla, “A Comparison of Lead Acid to Lithium-ion in Stationary Storage Applications,” AllCell Technologies LLC, Chicago, 2012.

[54] M. Hankins, Stand-alone Solar Electric Systems: The Earthscan Expert Handbook for Planning, Design and Installation, Washington, DC: Earthscan, 2010.

[55] C. Fernandez-Peruchena, A. Bernardos, M. Gaston, L. Ramirez, J. M. Vindel, L. Martin, D. Bermejo and J. Liria, "Solar Resource Mapping in Tanzania.," World Bank Group, Washington, DC, 2015.

[56] Tanzania Traditional Energy Development Organisation, "Rural Gasification Plant with Mini-Grids for Electrifying Kibindu Village, Bagamoyo District," Tanzania Traditional Energy Development Organisation, 2017. [Online]. Available: http://www.tatedo.org/viewpage.php?page_id=18.

[57] Energy and Environment Partnership, "Scaling up Geita Biomass Gasification Project in 4 Neighbouring Villages in Geita District," Energy and Environment Partnership, 2017. [Online].

[58] ESI Africa, “Tanzania to install 10,000 biogas plants by 2017,” 28 January 2017. [Online]. Available: https://www.esi-africa.com/news/tanzania-to-install-10000biogas-plants-by-2017/. [Accessed 18 November 2017].

[59] F. t. Heegde, "Domestic biogas plants: Sizes and dimensions," SNV, The Hague, 2010.

[60] L. Warnars and H. Oppenoorth, Bioslurry: A supreme fertilizer, The Hague: Hivos people unlimited, 2014.

[61] A. K. Mashauri, "Biomass Conversion to Energy in Tanzania: A Critique," in New Developments in Renewable Energy, Dar es Salaam, InTech, 2013, pp. 239269.

[62] Bergey Windpower, “7.5 kW Excel Off-Grid Reliability,” Bergey Windpower, 2017. [Online]. Available: http://bergey.com/products/wind-turbines/excel-7-5kwwind-turbine.

[63] H. Cetinay, F. Kuipers and N. Guven, "Optimal siting and sizing of wind farms," Renewable Energy, vol. 101, pp. 51-58, 2017.

[64] Bergey WindPower, "WindCad Turbine Performance Model," 2017. [Online]. Available: bergey.com/documents/2012/03/excel-7-5-r-battery-charging.xls. [Accessed 22 November 2017].

[65] LacPatrick, "Milk cooling and storage," LacPatrick, 16th May 2016. [Online]. Available: http://lacpatrick.com/milk-cooling-and-storage/. [Accessed 12 November 2017].

[66] B. Prasartkaew and S. Kumar, "A low carbon cooling system using renewable energy resources and technologies," Energy and Buildings, vol. 42, p. 1453-1462, 2010.

[67] M. Edwin and J. Sekhar, "Thermal performance of milk chilling units in remote villages working with the combination of biomass, biogas and solar energies," Energy, vol. 91, pp. $842-851,2015$.

[68] C. Erickson, "Rural milk preservation with the ISAAC solar icemaker," Energy for Sustainable Development, vol. 13, pp. 287- $291,2009$.

[69] R. Ghanbariamin, "Estimating the Economic Opportunity Cost of Capital for Kenya," February 2015. [Online]. Available: http://irep.emu.edu.tr:8080/xmlui/bitstream/handle/11129/1775/GhanbariaminRoksana.pdf?sequence=1. [Accessed 25 April 2017].

[70] Ministry of Finance and Economic Planning, "National Parameters," Ministry of Finance and Economic Planning, Rwanda, 2014. [Online]. Available: http://rwanda-cscf.cri-world.com/NationalParameters.php. [Accessed 25 April 2017].

[71] The Making Finance Work for Africa Partnership, “Tanzania: Apex bank cuts discount rate to 12 percent,” The Making Finance Work for Africa Partnership, 7 March 2017. [Online]. Available: https://www.mfw4a.org/news/news-details/article/2/tanzania-apex-bank-cuts-discount-rate-to-12-percent.html. [Accessed 25 April 2017].

[72] A. Kangondo, "Economics of Manure Disposal and Utilization in Morogoro Municipality, Tanzania," University of Agriculture, Morogoro, 2015.

[73] Ministry of Water and Irrigation, "Water Sector Status Report," Government of Tanzania, Dar es Salaam, 2013.

[74] E. Hennekens, “"Bioslurry always means profit." Success stories from Tanzania Domestic Biogas Program,” SNV Netherlands Development Organization, Dar es salaam, 2015.

[75] ILRI, “The MoremilkiT project: Baseline report,” International Livestock Research Institute, Nairobi, 2014.

[76] Trading Economics, “Tanzania Interest Rate,” Trading Economics, 2016. [Online]. Available: http://www.tradingeconomics.com/tanzania/interest-rate. [Accessed 27 August 2016].

[77] RiskAMP, "What is Monte Carlo Simulation?," [Online]. Available: https://www.riskamp.com/files/RiskAMP\%20-\%20Monte\%20Carlo\%20Simulation.pdf. [Accessed 22 January 2017].

[78] A. Uwe and Y. Ozgür, "Economic risk analysis of decentralized renewable energy infrastructures - A Monte Carlo Simulation approach," Renewable Energy, vol. 77, pp. 227-239, 2015.

[79] J. Lampe and J. Platten, "Triangular Distributions and Correlations: The simple math behind triangular distributions and correlations in Monte Carlo simulations," 9 June 2015. [Online]. Available: http://www.iceaaonline.com/ready/wp-content/uploads/2015/06/RI08-Presentation-Lampe-Triangular-Distributions.pdf. [Accessed 12 December 2017].

[80] M. Taboga, “The Monte Carlo method," Statlect, [Online]. Available: https://www.statlect.com/asymptotic-theory/Monte-Carlo-method. [Accessed 22 May 2018].

[81] T. Economics, “Tanzania Inflation Rate," Trading Economics, 2017. [Online]. Available: https://tradingeconomics.com/tanzania/inflation-cpi. [Accessed 12 November 2017].

[82] M. Franz, N. Peterschmidt, M. Rohrer and B. Kondev, "Mini-grid Policy Toolkit: Policy and Business Frameworks for Successful Mini-grid Roll-outs," European Union Energy Initiative Partnership Dialogue Facility (EUEI PDF), Eschborn, 2014.

[83] M. Nerkar, "Global Absorption Chillers Market : Growth Anticipated to be Driven by Steady Demand," Market Research Future, 1 February 2017. [Online]. Available: https://www.linkedin.com/pulse/global-absorption-chillers-market-growth-anticipated-driven-nerkar. [Accessed 12 December 2017].

[84] WISIONS of Sustainability, "Powering Milk Chilling Units with Biogas," Wuppertal Institute for Climate, Environment and Energy, 2014. [Online]. Available: http://www.wisions.net/projects/powering-milk-chilling-units-with-biogas\#project69. [Accessed 27 May 2018]. 
[85] New Leaf Dynamic, “Affordable Cooling,” New Leaf Dynamic, 2018. [Online]. Available: http://www.newleafdynamic.com/services/affordable-cooling/. [Accessed 27 May 2018].

[86] P. A. Garcia, "Techno-economic feasibility study of a small-scale biogas plant for treating market waste in the city of El Alto," KTH School of Industrial Engineering and Management, Stockholm, 2014.

[87] K. J. Lassner, "Financial and Economic Analyses of Biogas-to-Energy Projects in Brazil," [Online]. Available: https://dukespace.lib.duke.edu/dspace/bitstream/handle/10161/3688/Lassner_\%20Final\%20MP.pdf?sequence=1. [Accessed 12 December 2017].

[88] H. Katjiuongua and S. Nelgen, "Tanzania smallholder dairy value chain development: Situation analysis and trends," International Livestock Research Institute (ILRI), Dar es Salaam, 2014.

[89] J. Laramee and J. Davis, "Economic and environmental impacts of domestic bio-digesters: Evidence from Arusha, Tanzania," Energy for Sustainable Development, vol. 17, no. 3, pp. 296-304, 2013.

[90] W. Edelmann and H. Engeli, “The arbi Plug-Flow Digester in Tanzania - A medium-size Biogas Plant for Developing Countries,” Repic, NET, St. Ursen, 2015.

[91] A. Cameron, C. Derlagen and K. Pauw, "Options for reducing fertilizer prices for smallholder farmers in Tanzania," Food and Agriculture Organization of the United Nations, Rome, 2017.

[92] JLIFAD, "Southern Highlands Milkshed Development Project: Detailed design report," East and Southern Africa Division Programme Management Department, Dar es Salaam, 2016.

[93] Trading Economics, “Tanzania Interest Rate," 2017. [Online]. Available: http://www.tradingeconomics.com/tanzania/interest-rate. [Accessed 25 April 2017].

[94] G. Owens, "Best Practice Guide: Economic \& Financial Evaluation of Renewable Energy Projects," U.S. Agency for International Development, Washington DC, 2002.

[95] SNV world, "Tanzanian Domestic Biogas Program (TDBP)," World Access to Modern Energy, 2015. [Online]. Available: http://www.wame2015.org/casestudy/991/. [Accessed 12 December 2017].

[96] The Citizen, "Sh9bn committed to biogas project in rural Tanzania," The Citizen, 27 January 2016. [Online]. Available: http://www.thecitizen.co.tz/News/Business/Sh9bn-committed-to-biogas-project-in-rural-Tanzania/1840414-3050586-15h8ku6z/index.html. [Accessed 12 December 2017].

[97] Contracts for Difference and CFDs Trading, "History and the CFD revolution!," Contracts for Difference and CFDs Trading, 2015. [Online]. Available: http://www.contracts-for-difference.com/contracts-for-differences.html. [Accessed 25 April 2017].

[98] R. Foster, B. Dugdill, B. Knight, A. Faraj, J. Mwove and W. Hadley, "Solar Farm Milk Cooling: Smallholder Dairy Farmer Experience in Kenya," in International Solar Energy Society Conference Proceedings, Daegu, Korea, 2015.

[99] The Centre for Agricultural Mechanization and Rural Technology, "Biogas Technologies," The Centre for Agricultural Mechanization and Rural Technology, 2018. [Online]. Available: http://camartec.go.tz/biogas.html. [Accessed 29 May 2018] 
A risk-adjusted techno-economic analysis for renewable-based milk cooling in remote dairy farming communities in East Africa

\section{Highlights}

1. Renewable energy can be used to boost dairy production in rural areas in Tanzania.

2. Renewable energy resource analysis and system design for small-scale milk cooling.

3. An economically viable solution for biogas milk cooling is proposed.

4. A probabilistic Monte Carlo simulation of project investment risks. 